MILENE SCHMIDT DO AMARAL E LUNA

\title{
INERVAÇÃO NORADRENÉRGICA NA ATIVAÇÃO DA GLÂNDULA DE VENENO DA SERPENTE Bothrops jararaca
}

Dissertação de Mestrado apresentada ao Instituto de Ciências Biomédicas da Universidade de São Paulo, para a obtenção do Título de Mestre em Ciências. 


\section{INERVAÇÃO NORADRENÉRGICA NA ATIVAÇÃO DA GLÂNDULA DE VENENO DA SERPENTE Bothrops jararaca}

Dissertação de Mestrado apresentada ao Instituto de Ciências Biomédicas da Universidade de São Paulo, para a obtenção do Título de Mestre em Ciências.

Área de concentração:

Biologia Celular e Tecidual

Orientadora:

Dra. Norma Yamanouye 


\section{Dedicatárias}

Aos mens pais, Creusa e Josué, pelo enorme incentivo e apoio que sempre me impulsionaram a seguir meus caminhos de forma construtiva.

Muito Obrigada!

Aos mens irmãos, em especial

Nelise pelo sew exemplo de determinação e coragem, pela sua sincera amizade e paciência. Muito Obrigada! 
Ao Marcio pelo total incentivo, apoio, carinho e, sobretudo, pela enorme paciência, por todo amor e respeito. Muito Obrigada! 
À Dra. Norma Yamanouye, pela orientação, apoí e compreensão sempre presentes e pela determinação e amizade, expresso minha profunda gratidão pelos ensinamentos que contribuiram muito para mew crescimento profissionale pessoal.

Muito Obrigada! 


\section{Agradecimentas}

São inúmeras as pessoas a quem desejo agradecer pela importância que tiveram durante a realização deste trabalho:

Ao Laboratório de Herpetologia do Instituto Butantan pela classificação e fornecimento das serpentes Bothrops jararaca. Em especial ao Sávio Stefanini Sant'Anna pela atenção dispensada.

Ao Órgão de Fomento FAPESP pelo Auxílio Financeiro e pela Bolsa de Mestrado concedida durante a realização deste trabalho (04/11611-1).

À Profa. Dra. Zulma S. Ferreira, pela colaboração nos ensaios de gel de retardo e pelas sugestões.

À Profa. Dra. Telma Maria Tenório Zorn, pela sua orientação durante a realização do Programa de Aperfeiçoamento de Ensino (PAE) e pelos seus valiosos conselhos.

Aos colegas do Laboratório de Cronofarmacologia do Instituto de Biociências - USP, em especial Érika e Pedro, pelo apoio dispensado nos ensaios de gel de retardo.

A Celiana, secretária do Programa de Pós-graduação em Biologia Celular e Tecidual do Departamento de Biologia Celular e do Desenvolvimento do Instituto de Ciências Biomédicas - USP, que sempre esclareceu todas as dúvidas.

Ao Dr. Paulo Lee Ho do Laboratório de Biotecnologia do Instituto Butantan por ceder a sala escura para revelação dos filmes de auto-radiografia.

Aos funcionários do Laboratório de Farmacologia do Instituto Butantan pelo excelente suporte e pela agradável convivência. Em especial ao Wilson D'Avila por tornar nossos almoços mais divertidos. 
Aos pesquisadores do Laboratório de Farmacologia do Instituto Butantan que direta ou indiretamente, contribuíram para a realização deste trabalho.

Aos colegas e amigos do Laboratório de Farmacologia pela amizade e agradável convivência.

Aos amigos Thiago Macedo de Abreu Hortêncio pela agradável companhia e ajuda nos complicados softwares e Fernanda Sakai pela agradável convivência e amizade.

As amigas Celine Marie de Kerchove e Aline Oliveira Teodoro que deixaram saudades no laboratório, pela convivência enriquecedora, amizade e boas gargalhadas.

Agradecimento especial aos amigos Camila Eduardo Marinho, Mariana Bayerlein Zablith e Leandro Magalhães pela maravilhosa convivência, amizade e bom-humor sempre presentes. Obrigada também pelos momentos de discussões científicas que foram essenciais em muitos momentos do meu mestrado.

Aos amigos Gustavo, Wyara, João e Carlos pelos momentos divertidíssimos.

À minha grande amiga Carol que do seu jeito colaborou para minha formação profissional e pessoal.

À minha futura cunhada e amiga Marilda pelos conselhos, e apoio em momentos importantes e pela amizade. 
"Diante de mim havia duas estradas ew escolhi a estrada menos percorrida e isso fez toda a diferença." Robert Frost 


\section{$\underline{\text { Resuma }}$}

Luna, M. S. A. Inervação noradrenérgica na ativação da glândula de veneno da serpente Bothrops jararaca. 2007. 86 f. Dissertação (Mestrado em Ciências) Instituto de Ciências Biomédicas, Universidade de São Paulo, São Paulo, 2007.

Dados anteriores do laboratório mostraram que a estimulação da inervação noradrenérgica, logo após extração de veneno, desencadeia o ciclo de produção de veneno em glândulas de veneno da serpente Bothrops jararaca. O objetivo desta dissertação foi verificar quais os mecanismos responsáveis por esse efeito. Neste

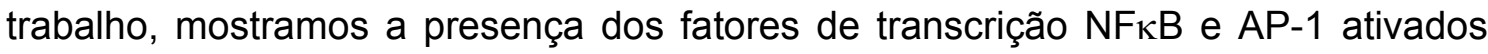
em células secretoras da glândula de veneno no estado quiescente. Estudos in vivo mostraram que a extração de veneno promove um aumento na ativação de NFKB e AP-1 em relação ao basal. O pico de ativação do NFkB nas serpentes fêmeas ocorreu 30 minutos $(33,21 \pm 7,16 \%, n=5)$ e nos machos 60 minutos $(38,86 \pm 9,61 \%$, $\mathrm{n}=4$ ) após a extração de veneno. No entanto, o pico de ativação do AP-1 para ambas as serpentes fêmeas e machos ocorreu 60 minutos $(91,96 \pm 25,65 \%$, n=4 e $56,07 \pm 14,96 \%, n=5$, respectivamente) após a extração de veneno, sendo a ativação de AP-1 nas serpentes fêmeas significativamente maior do que nos machos. Esses dados mostram um dimorfismo sexual na ativação dos fatores de transcrição na glândula de veneno e a participação desses fatores no desencadeamento do ciclo de produção de veneno. Estudos in vitro mostraram que noradrenalina $\left(10^{-4} \mathrm{M}, 30\right.$ minutos) é capaz de aumentar a ativação de NFKB $(24,60 \pm$ $8,83 \%, n=6)$ e AP-1 $(12,01 \pm 4,21 \%, n=3)$ em células secretoras quiescentes da glândula de veneno. Após 60 minutos de incubação (pico máximo da ativação de AP-1 após extração de veneno), noradrenalina é capaz ainda de aumentar a ativação de AP-1 $(19,19 \pm 5,92 \%, n=4)$. A estimulação do adrenoceptor $\beta$ por isoprenalina ( $3 \times 10^{-4} \mathrm{M}, 30$ minutos) aumentou a ativação de ambos fatores de transcrição NFאB $(19,31 \pm 5,29 \%, n=6)$ e AP-1 $(25,49 \pm 7,73 \%, n=3)$, enquanto que a estimulação do adrenoceptor $\alpha$ por fenilefrina $\left(3 \times 10^{-4} \mathrm{M}, 30\right.$ minutos) aumentou a ativação de $\mathrm{NF} \kappa \mathrm{B}(30,35 \pm 4,58 \%, \mathrm{n}=8)$, e reduziu a ativação de AP-1 $(-12,67 \pm$ $2,94 \%, n=9$ ). No entanto, quando as células foram incubadas com isoprenalina ou 
fenilefrina por 60 minutos, ambos agonistas foram capazes de aumentar a ativação de AP-1 (25,52 $\pm 12,30 \%, n=5$ e 13,93 \pm 6,81\%, $n=6$, respectivamente). Mostramos também que a extração de veneno promove modificações na síntese de proteínas da glândula de veneno e não na síntese de toxinas do veneno e que a estimulação de ambos os adrenoceptores $\alpha$ e $\beta$ estão envolvidos neste processo. Em conclusão, a extração de veneno estimula a inervação noradrenérgica e a noradrenalina liberada atuando em adrenoceptores $\alpha$ e $\beta$ ativam fatores de transcrição que regulam a síntese de proteínas da glândula de veneno que provavelmente são essenciais para sua ativação e posterior produção de veneno. Esses novos dados proporcionam um melhor entendimento dos mecanismos de produção e secreção de veneno em glândulas de serpentes Bothrops jararaca. Este é um passo importante na busca de uma ferramenta apropriada para produção de veneno in vitro, fornecendo subsídios necessários para obtenção de uma linhagem de células secretoras funcionais da glândula de veneno.

Palavras-chave: Inervação noradrenérgica. Adrenoceptores. Fatores de transcrição. Glândula de veneno. Serpente. Bothrops jararaca. 


\section{Alestract}

Luna, M. S. A. Noradrenergic innervation on activation of venom gland Bothrops jararaca snake. 2007. 86 f. Master thesis (sciences) - Instituto de Ciências Biomédicas, Universidade de São Paulo, São Paulo, 2007.

Previous studies showed that stimulation of noradrenergic innervation by venom extraction triggers the venom production cycle in the venom gland of Bothrops jararaca snake. The aim of this study was to verify the mechanisms involved in this process. In the present study, we showed the presence of activated transcription factors NFKB and AP-1 in quiescent secretory cells of venom gland. In vivo studies showed that venom extraction increase the activation of NFKB and AP-1 over basal. The peak of NFKB activation in female snakes occurred 30 minutes $(33.21 \pm 7.16 \%$, $\mathrm{n}=5)$ and in male snakes 60 minutes (38.86 $\pm 9.61 \%, \mathrm{n}=4)$ after venom extraction. The peak of AP-1 activation for both female and male snakes occurred 60 minutes $(91.96 \pm 25.65 \%, n=4$ and $56.07 \pm 14.96 \%, n=5$, respectively) after venom extraction, but the activation of AP-1 is significantly greater in female than in male snakes. These data show a sexual dimorphism in NFאB and AP-1 activation in snake venom gland and the role of these transcription factors in triggering the venom production cycle. In vitro studies showed that noradrenaline $\left(10^{-4} \mathrm{M}, 30\right.$ minutes) is able to increase the activation of NFKB $(24.60 \pm 8.83 \%, n=6)$ and AP-1 $(12.01 \pm 4.21 \%, n=3)$ in quiescent secretory cells of venom gland. After 60 minutes incubation (the highest activation of AP-1 after venom extraction), noradrenaline is still able to increase the activation of AP-1 (19.19 $\pm 5.92 \%, n=4)$. Stimulation of $\beta$ adrenoceptor with isoprenaline $\left(3 \times 10^{-4} \mathrm{M}, 30\right.$ minutes $)$ increased the activation of both transcription factors NFKB (19.31 $\pm 5.29 \%, n=6)$ and AP-1 (25.49 $\pm 7.73 \%, n=3)$, however,

stimulation of $\alpha$ adrenoceptor with phenylephrine $\left(3 \times 10^{-4} \mathrm{M}, 30\right.$ minutes) increased the activation of $N F \kappa B(30.35 \pm 4.58 \%, n=8)$, but decreased the activation of AP-1 $(-12.67 \pm 2.94 \%, n=9)$. When the cells were incubated with isoprenaline or phenylephrine for 60 minutes, both agonists were able to increase the activation of AP-1 (25.52 $\pm 12.30 \%, n=5$ and $13.93 \pm 6.81 \%, n=6$, respectively). We also showed that venom extraction promotes changes in synthesis of proteins of the venom gland, 
but not synthesis of toxins of the venom and stimulation of both $\alpha$ - and $\beta$ adrenoceptors are involved in this process. In conclusion, venom extraction stimulates noradrenergic innervation and noradrenaline released in the venom gland acting on $\alpha$ and $\beta$ adrenoceptors can activate transcription factors that regulate the synthesis of proteins of venom gland that probably are essential to activate venom gland to produce venom. The new data obtained here allow us to better understand the mechanisms involved in venom production and secretion in Bothrops jararaca venom gland and will give us new insights to establish functional secretory cell line from venom gland, in order to obtain venom with activity in vitro.

Keywords: Noradrenergic innervation. Adrenoceptors. Transcription factors. Venom gland. Snake. Bothrops jararaca. 


\section{Lista de Figuras}

Figura 1: Crânio e Mandíbula de serpente com aparelho inoculador do tipo solenóglifo.

Figura 2: Serpente brasileira, peçonhenta, Bothrops jararaca, fotografada por Giuseppe Puorto. 22

Figura 3: Distribuição geográfica da serpente Bothrops jararaca no Brasil. 22

Figura 4: Glândula de veneno de serpentes Viperidae. 24

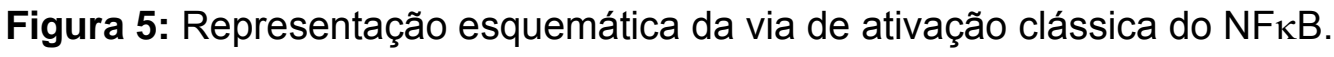
33

Figura 6: Decurso temporal da ativação do $\mathrm{NF} \kappa \mathrm{B}$ promovida pela extração de veneno das glândulas da serpente Bothrops jararaca. 50

Figura 7: Decurso temporal da ativação do AP-1 promovida pela extração de veneno das glândulas da serpente Bothrops jararaca. 51

Figura 8: Estimulação dos adrenoceptores $\alpha$ e $\beta$ ativa NFאB em células secretoras quiescente da glândula de veneno da Bothrops jararaca. 53

Figura 9: Estimulação dos adrenoceptores $\alpha$ e $\beta$ regula a ativação de AP-1 em células secretoras quiescentes da glândula de veneno da Bothrops jararaca. 55

Figura 10: A estimulação dos adrenoceptores $\alpha$ e $\beta$ não participa diretamente na síntese de toxinas do veneno. 57

Figura 11: Composição protéica das glândulas de veneno das serpentes Bothrops jararaca fêmea e macho nos diferentes estágios do ciclo de produção de veneno. 59 Figura 12: Efeito da reserpina e da estimulação dos adrenoceptores $\alpha$ e $\beta$ na composição protéica da glândula de veneno. 


\section{Sumária}

1 Intraduçãa 19

1.1 Bothrops jararaca 21

1.2 Glândula de veneno 23

1.3 Glândulas salivares 26

$1.4 \quad$ Adrenoceptores 27

1.5 Relevância 35

2 Olijetivas 36

3 Materiais e Métadas 38

3.1 Tampões e Soluções 39

3.2 Drogas e Reagentes 39

3.3 Animais 41

3.4 Glândulas de veneno 41

3.5 Dispersão de células secretoras da glândula de veneno 41

3.6 Extrato total de glândula de veneno 42

3.7 Extratos nucleares de glândula de veneno e de células secretoras dispersas

42

3.8 Eletroforese em gel de poliacrilamida na presença de SDS (SDS-PAGE) _ 43

3.9 Determinação de proteína 43

3.10 Ensaio de gel de retardo para NFKB e AP-1 44

3.11 Densitometria 44 
3.12.1 Determinação de fatores de transcrição NFאB e AP-1 na glândula de veneno __

3.12.1.1 Estudo in vivo: Extração de veneno na ativação de fatores de transcrição ___ 45

3.12.1.2 Estudo in vitro: Estimulação dos adrenoceptores $\alpha$ e $\beta$ na ativação dos fatores de transcrição___ 45

3.12.2 Participação dos adrenoceptores $\alpha$ e $\beta$ na síntese de proteínas ___ 46

3.12.2.1 Veneno___ 46

3.12.2.2 Glândula de veneno ___ 46

3.12.2.2.1 Análise do perfil protéico da glândula de veneno durante o ciclo de produção de veneno ___ 46

3.12.2.2.2 Efeito da estimulação dos adrenoceptores na composição protéica da glândula de veneno ___ 47

3.13 Análise estatística___ 47

4 Resultadas__ 48

4.1 Extração de veneno aumenta ativação de NFKB em células secretoras da glândula de veneno da Bothrops jararaca 49

4.2 A estimulação dos adrenoceptores $\alpha$ e $\beta$ na ativação de NFkB e AP-1 em células secretoras da glândula de veneno da Bothrops jararaca 52

4.3 Participação dos adrenoceptores $\alpha$ e $\beta$ na síntese de proteínas do veneno da serpente Bothrops jararaca 56

4.4 Análise do perfil protéico de extratos de glândula de veneno nos diferentes estágios do ciclo de produção de veneno 58

4.5 Participação dos adrenoceptores $\alpha$ e $\beta$ na síntese de proteínas da glândula de veneno da serpente Bothrops jararaca 60

5 Discussãa 62

6 Canclusãa 70 
$1 \underline{\text { Intraduçãa }}$ 
O Brasil possui uma fauna rica em serpentes, mas muitas espécies dessa fauna ainda são pouco estudadas. Existe uma idéia aproximada desta riqueza composta por cerca de 265 espécies, classificadas dentro de 73 gêneros, reunidos em 9 famílias. De todo esse elenco apenas duas famílias, Elapidae e Viperidae, agregam as espécies peçonhentas, isto é, aquelas que produzem toxinas em glândulas especializadas e têm aparelhos apropriados para inoculá-las (MELGAREJO, 2003).

A peçonha de serpentes é, provavelmente, a mais complexa de todos os venenos. Contém aproximadamente vinte componentes diferentes, sendo que mais de $90 \%$ do peso seco do veneno é constituído por proteínas, compreendendo grande variedade de enzimas, toxinas não-enzimáticas, e proteínas não-tóxicas (WARRELL, 1989). A função de cada um desses componentes, bem como seus papéis no envenenamento humano ainda não estão totalmente esclarecidos.

O estudo dos venenos de serpentes tem propiciado a elucidação de diversos mecanismos fisiológicos e farmacológicos. O estudo do veneno de Bothrops jararaca permitiu o descobrimento da bradicinina (ROCHA E SILVA, 1949) e dos peptídeos potenciadores de bradicinina (FERREIRA, 1965), que levaram à síntese do captopril, um inibidor da enzima conversora de angiotensina I, hoje amplamente utilizada no tratamento de hipertensão arterial, na insuficiência cardíaca congestiva e na doença arterial coronária (ONDETTI et al., 1971). Bothrojaracina é uma proteína que também foi isolada do veneno de Bothrops jararaca e foi descrita como o primeiro inibidor específico de trombina (ZINGALI et al., 1993), ou seja, a bothrojaracina é um potente agente anti-trombótico que pode ser utilizado para o desenvolvimento de novas drogas (ZINGALI et al., 2005).

Os viperídeos representam o mais importante grupo de serpentes para saúde pública, pois são responsáveis pela maioria dos acidentes ofídicos registrados no Brasil. Neste grupo insere-se a serpente peçonhenta, brasileira Bothrops jararaca, o animal de estudo utilizado neste trabalho. 


\subsection{Bothrops jararaca}

A família Viperidae é formada por serpentes com aparelho inoculador do tipo solenóglifo (Figura 1), caracterizado por dentes longos, dotados de canais internos, localizados na região anterior do maxilar superior e possui um mecanismo craniano complexo que permite grande abertura bucal e no momento do ataque um giro de 90 para injetar o veneno (GOMES; PUORTO, 1993; MELGAREJO, 2003). A serpente Bothrops jararaca (Figura 2) pertence à família Viperidae e tem grande capacidade de adaptação, ocupando e colonizando áreas silvestres, agrícolas, suburbanas e até urbanas. Estas serpentes têm atividade noturna e possuem hábitos terrestres (SAZIMA, 1988).

\section{A}

B
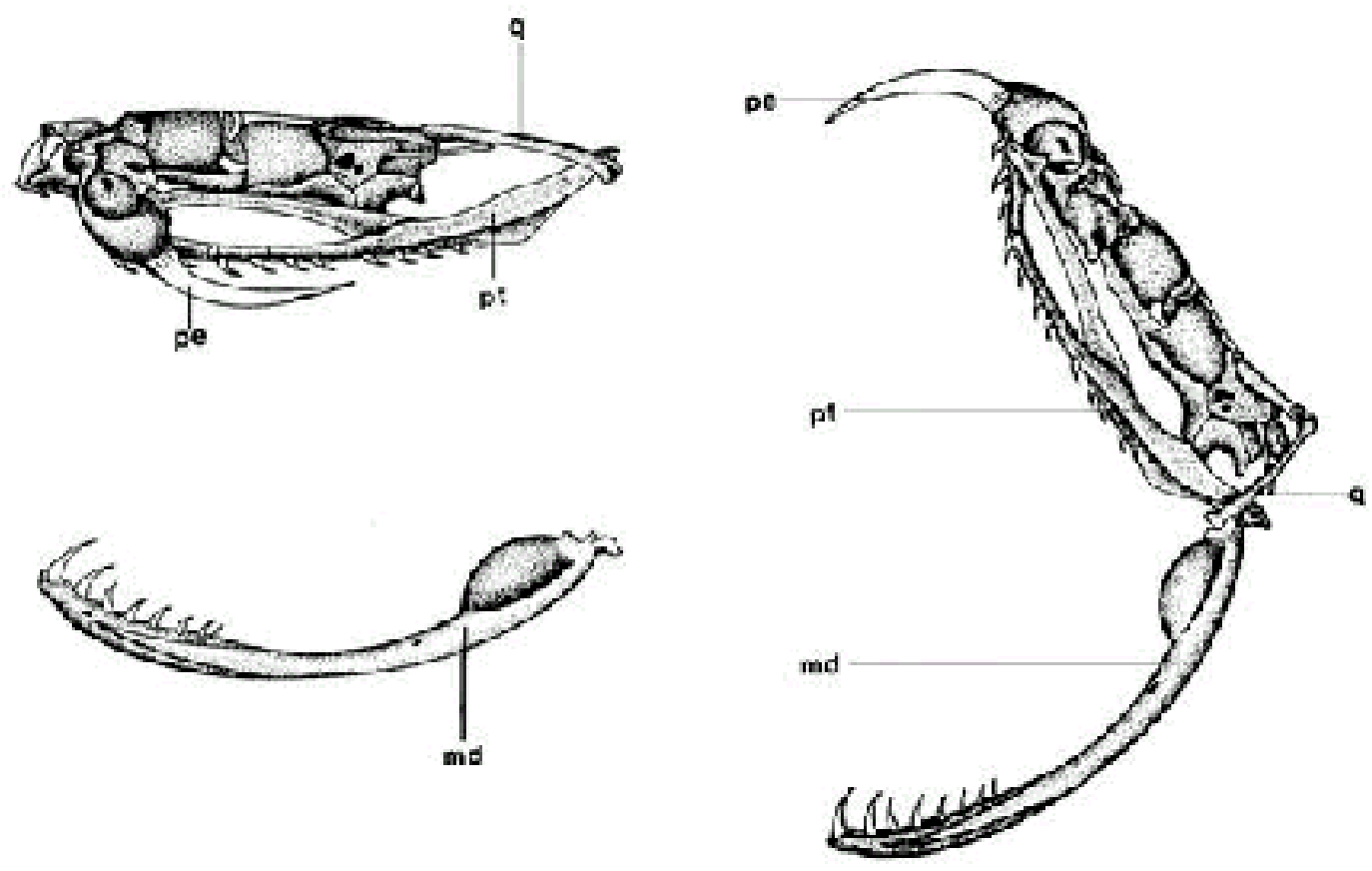

Figura 1: Crânio e mandíbula de serpente com aparelho inoculador do tipo solenóglifo. A: visão lateral do crânio com mandíbula fechada. B: Crânio e mandíbula em posição de abertura bucal máxima. pe: presa, pt: pterigoideo, q: quadrado, md: mandíbula. (GOMES; PUORTO, 1993). 


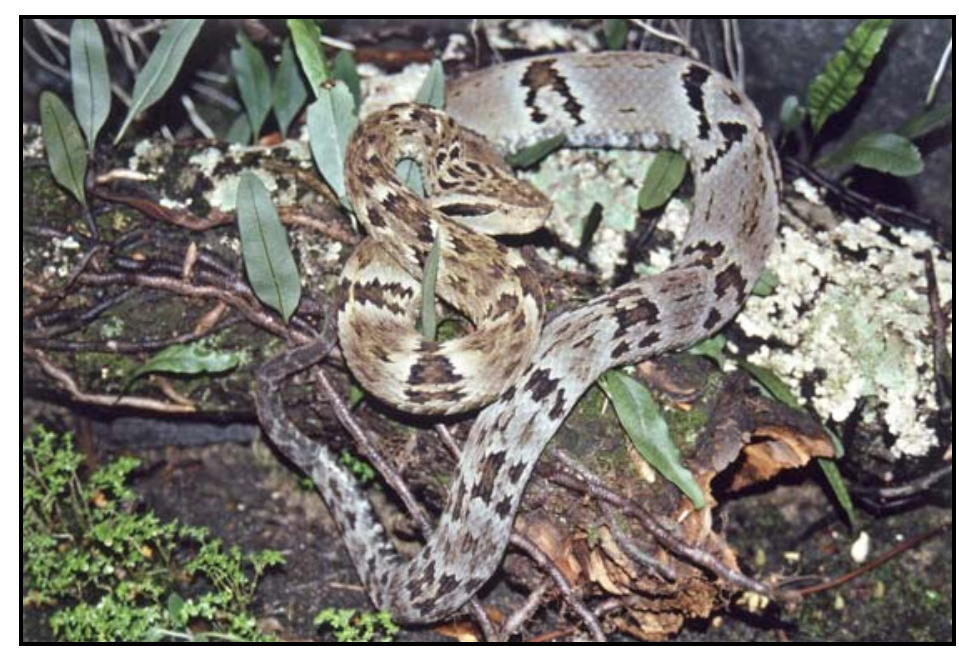

Figura 2: Serpente brasileira, peçonhenta, Bothrops jararaca, fotografada por Giuseppe Puorto.

Esta espécie é encontrada na Região Sul e Sudeste, habitando desde o sul da Bahia até Rio Grande do Sul (Figura 3) e é a principal responsável pelos acidentes ofídicos nesta região geográfica (MELGAREJO, 2003). Baseados em dados do Ministério da Saúde, são relatados anualmente, cerca de 20.000 acidentes ofídicos no Brasil, sendo que, aproximadamente $90 \%$ são acidentes botrópicos, com letalidade de 0,3\% nos casos tratados (ARAÚJO; SANTALÚCIA; CABRAL, 2003).

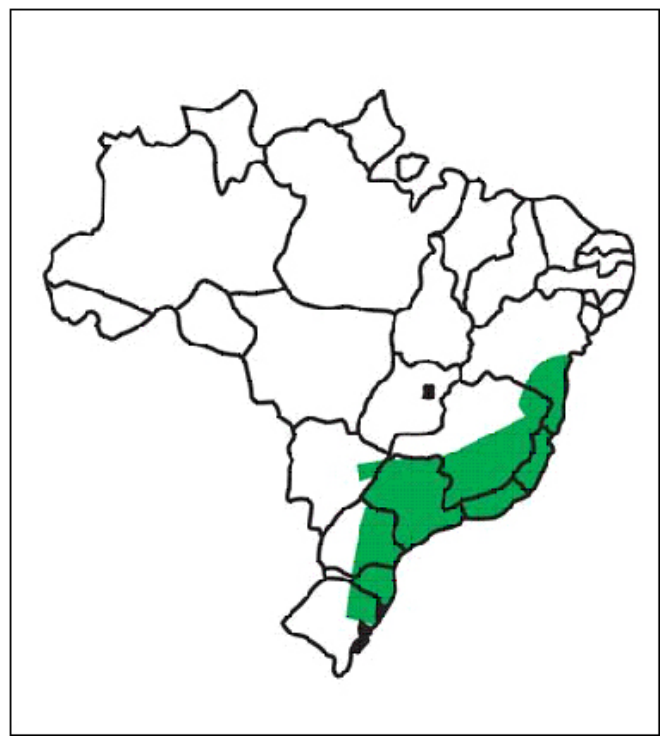

Figura 3: Distribuição geográfica da serpente Bothrops jararaca no Brasil. (FUNASA, 2001). 


\subsection{Glândula de veneno}

Paralelo com a evolução da dentição e da caixa craniana ocorreu a evolução da glândula de veneno, provavelmente a partir de estruturas salivares especializadas do lábio superior e a evolução do músculo compressor de glândula, derivado da musculatura temporal anterior. A serpente possui um par de glândulas de veneno que se localizam na região temporal, posterior aos olhos, embaixo da pele, sendo uma de cada lado da cabeça (Figura 4a). Ligamentos e músculos fixam a glândula ao crânio, dentre os quais se destaca o músculo compressor de glândula, que detém o principal papel no processo de inoculação do veneno durante o ataque (Figura 4a), (KOCHVA; GANS, 1967; KARDONG, 1982; MELGAREJO, 2003).

O aparelho glandular de veneno possui quatro regiões bem definidas: a glândula principal de veneno, que constitui a parte secretora e ocupa toda a porção posterior; o ducto primário, a glândula acessória e o ducto secundário que conecta com o canal do dente inoculador de veneno (Figura 4b), (KOCHVA; GANS, 1967; GOMES; PUORTO, 1993).

A glândula principal é composta por pelo menos quatro tipos celulares distintos: células epiteliais secretoras, presentes em maior quantidade na glândula (aproximadamente 79\%); células ricas em mitocôndrias (aproximadamente 2\%), células horizontais (10\%) e células escuras (9\%) (MACKESSY, 1991). A estrutura morfológica das glândulas de veneno de serpentes Viperidae tem sido extensamente estudada, e uma característica importante é que o produto de secreção é estocado no lumen central presente nessas glândulas e nos pequenos ductos da glândula principal (Figura 4b) e não em vesículas secretoras intracitoplasmática, como ocorrem em glândulas de veneno de serpentes das famílias Elapidae e Colubridae (KOCHVA, 1978; YOSHIE; ISHIYAMA; OGAWA, 1982; GOPALAKRISHNAKONE; KOCHVA, 1990; GOPALAKRISHNAKONE; KOCHVA, 1993) ou ainda de glândulas exócrinas de mamíferos (JAMIESON; PALADE, 1967a; JAMIESON; PALADE, 1967b; AMSTERDAM; OHAD; SHRAMM, 1969; MELDOLESI, 1976). 

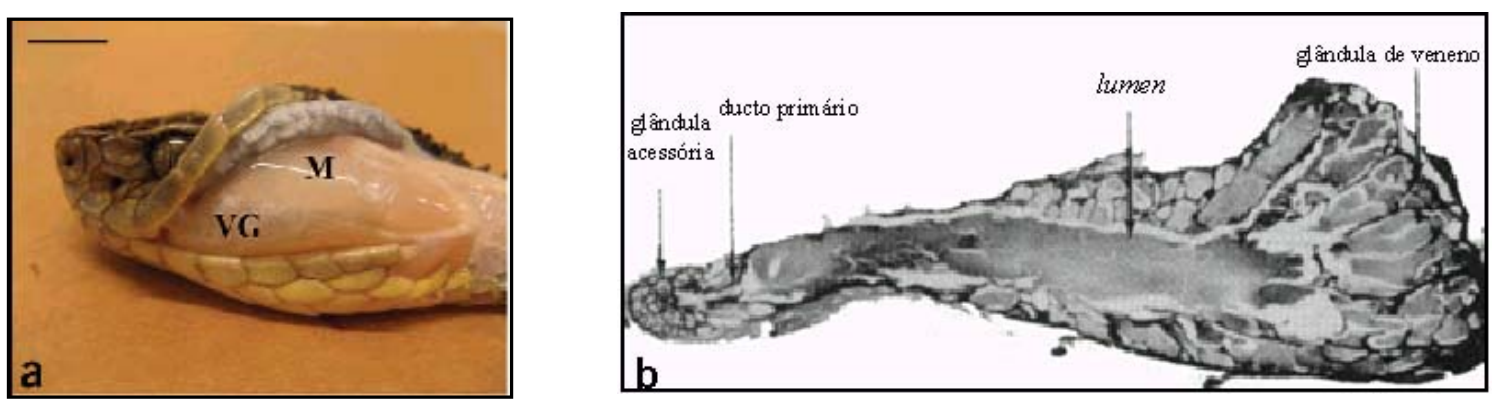

Figura 4: Glândula de veneno de serpentes Viperidae. (a) vista lateral da cabeça da serpente Bothrops jararaca mostando a localização da glândula de veneno. VG: glândula de veneno, M: músculo compressor de glândula (YAMANOUYE et al., 2007); (b) corte sagital do aparelho glandular de veneno da serpente Vipera palaestinae (KOCHVA, 1987).

O processo de produção e secreção de veneno ocorre após uma diminuição do conteúdo do lumen da glândula, seja após uma picada ou por extração manual de veneno, e é acompanhado por mudanças morfológicas e bioquímicas no epitélio secretor da glândula de veneno (BEN-SHAUL; LIFSHITZ; KOCHVA, 1971; ROTENBERG; BAMBERGER; KOCHVA, 1971; ZAGO, 1971; SCHAEFFER et al., 1972a; SCHAEFFER et al., 1972b; ORON; BDOLAH, 1973; KOCHVA, 1978; BDOLAH, 1979, CARNEIRO et al., 1991; MACKESSY, 1991; SALOMÃO, 1991). As glândulas de veneno de serpentes que não sofreram extração de veneno por um longo período (1 a 2 meses) estão cheias de veneno, sendo que as células secretoras estão na forma cubóide, as cisternas do Retículo Endoplasmático Granular (REG) estão estreitas e paralelas. Após a extração, a quantidade de veneno no lumen diminui iniciando-se um novo ciclo de síntese de veneno, em que as células epiteliais passam da forma cubóide para forma colunar, as cisternas do REG se expandem e o veneno é sintetizado. Em Vipera palaestinae (BEN-SHAUL; LIFSHITZ; KOCHVA, 1971; ROTENBERG; BAMBERGER; KOCHVA, 1971), Crotalus durissus terrificus (DE LUCCA et al., 1974) e Bothrops jararacussu (CARNEIRO et al., 1991) as células alcançam a altura máxima em aproximadamente 4 dias após a extração. Na Vipera palaestinae (ROTENBERG; BAMBERGER; KOCHVA, 1971) a maior quantidade de RNAm por glândula é encontrada nesse estágio e a maior parte do volume celular é ocupada pelo REG. Apesar das glândulas de veneno estarem ativadas nesse estágio do ciclo, poucas vesículas são encontradas nas células secretoras, pois todo material sintetizado é exocitado e 
estocado no lumen glandular. O pico de atividade de síntese e secreção de proteínas, na maioria das espécies investigadas, ocorre do $4^{\circ}$ ao $15^{\circ}$ dia (KOCHVA, 1978). Após este período, as células secretoras da glândula diminuem de tamanho e gradualmente a célula assume a organização do estado quiescente (BEN-SHAUL; LIFSHITZ; KOCHVA, 1971; ORON; BDOLAH, 1973). O ciclo completo de produção de veneno dura de 30 a 50 dias, sendo significativamente mais longo quando comparado ao ciclo de produção de proteínas em pâncreas de mamíferos e em glândulas salivares (JAMIESON; PALADE, 1967a; JAMIESON; PALADE, 1967b; AMSTERDAM; OHAD; SHRAMM, 1969).

Quanto aos mecanismos celulares envolvidos na produção e secreção de veneno, estudos realizados por Yamanouye et al., 1997 demonstram que a inervação noradrenérgica está envolvida na produção e secreção de veneno, uma vez que o bloqueio da atividade simpática por reserpina bloqueou a produção e secreção de veneno em glândulas ativadas por extração de veneno. A estimulação de ambos os adrenoceptores $\alpha$ e $\beta$ estão envolvidos nesses processos. Para aprofundar o conhecimento sobre os mecanismos celulares que regulam o ciclo de produção e secreção de veneno em serpentes Bothrops jararaca, tornou-se necessário compreender como a estimulação dos adrenoceptores $\alpha$ e $\beta$, localizados na célula secretora, poderia levar à estimulação da síntese e secreção protéica. Para tanto, os adrenoceptores $\alpha$ e $\beta$ da glândula de veneno foram caracterizados, e estes diferem dos descritos em mamíferos em sua sensibilidade a ligantes clássicos $\alpha$ e $\beta$, respectivamente (YAMANOUYE et al., 2000; KERCHOVE et al., 2004).

Os adrenoceptores $\beta$ estão acoplados à proteína Gs, visto que sua estimulação leva a um aumento na concentração de monofosfato de adenosina cíclica (AMPc). Além disso, a estimulação dos adrenoceptores $\beta$ ativa o influxo de cálcio via canais ativados por voltagem (VOC) e ativados por receptores (ROC), além de mobilizar cálcio de estoques sensíveis a tapsgargina (YAMANOUYE et al., 2000; ZABLITH, 2007). Vale ressaltar que o aumento de AMPc após estimulação dos adrenoceptores $\beta$ só ocorre em células no estado quiescente (glândulas que não sofreram extração de veneno) e não no seu estágio máximo de ativação (4 dias após a extração de veneno) (YAMANOUYE et al., 2000) e o aumento da concentração citosólica de cálcio é significativamente maior em células quiescentes (ZABLITH, 2007). 
Os adrenoceptores $\alpha$ são do subtipo $\alpha_{1 D}$ e estão acoplado à proteína Gq, visto que sua estimulação ativa a fosfolipase $C$ (PLC) levando à hidrólise do bifosfato de fosfatidilinositol $\left(\mathrm{PIP}_{2}\right)$, com a conseqüente produção de trifosfato de inositol $\left(\mathrm{IP}_{3}\right)$ e diacilglicerol (DAG), promovendo a liberação de cálcio dos estoques intracelulares sensíveis a tapsgargina e ativação de proteína quinase $C$ $(\mathrm{PKC})$, respectivamente. Além disso, esses receptores ativam a cascata da quinase ativada por mitógenos (MAPK), ERK1/2, sendo que a etapa inicial dessa ativação é via PKC (KERCHOVE, 2005; KERCHOVE et al., prelo). Esses receptores quando estimulados são prontamente dessensibilizados, sendo essa dessensibilização de longa duração (30 dias).

A dessensibilização prolongada dos adrenoceptores $\alpha$ e $\beta$ possibilitou a descoberta, in vivo, da importância da estimulação desses adrenoceptores para o início da síntese do veneno (KERCHOVE et al., 2004; ZABLITH, 2007). Portanto, a extração de veneno ativa a inervação noradrenérgica e a noradrenalina liberada atuando tanto em adrenoceptores $\alpha$ como $\beta$ desencadeia uma sinalização intracelular complexa que leva a glândula de veneno a iniciar um novo ciclo de produção de veneno.

\subsection{Glândulas salivares}

As glândulas salivares estão localizadas na cavidade oral e produzem saliva, um fluído com funções digestivas, lubrificantes e protetoras. As glândulas salivares menores produzem $10 \%$ da saliva. Os três pares de glândulas salivares maiores (submandibular, sublingual e parótida) secretam $90 \%$ da saliva total e são formadas por uma porção secretora e por um sistema de ductos (JUNQUEIRA; CARNEIRO, 2004).

A porção secretora possui três tipos de células: serosas, mucosas e mioepiteliais não-secretoras. O sistema de ductos, constituído pelos ductos intercalares, estriados e excretores, contínuo a porção secretora, modifica e transporta saliva para cavidade oral (JUNQUEIRA; CARNEIRO, 2004).

As glândulas salivares de mamíferos são inervadas por fibras nervosas do sistema autônomo simpático e parassimpático. Os nervos autônomos simpáticos e 
parassimpáticos trabalham de forma harmoniosa controlando a liberação de secreções (PROCTOR; CARPENTER, 2007). A função secretora das glândulas salivares é regulada através de ações de diferentes receptores como os adrenoceptores $\alpha$ e $\beta$, os colinoceptores-muscarínicos e os receptores de peptídeos (BAUM, 1993; BAUM; WELLNER, 1999).

O adrenoceptor $\alpha$ regula a secreção de fluídos, eletrólitos, amilase e mucinas (QUISSELL; BARZEN; DEISHER, 1993; KLEIN, 2002). Ambos os subtipos $\alpha_{1 \mathrm{~A}}$ e $\alpha_{1 \mathrm{~B}}$ de adrenoceptores são expressos em glândulas submandibulares de ratos e humanos, entretanto, foi detectada uma maior concentração do RNAm do subtipo $\alpha_{1 \mathrm{~A}}$ do que $\alpha_{1 \mathrm{~B}}$ em ambas as glândulas, indicando uma similaridade no padrão de expressão dos subtipos do adrenoceptor $\alpha_{1}$ em ratos e humanos (NISHIURA; GAO; ABE, 2001; HUANG et al., 2006).

Em glândulas salivares, a ativação do adrenoceptor $\beta$ tem uma participação importante na expressão e secreção de proteínas e no desenvolvimento e crescimento pós-natal (BARKA, 1990; YEH et al., 2005). Os subtipos $\beta_{1}$ e $\beta_{2}$ são expressos na glândula submandibular de coelhos, sendo que o subtipo $\beta_{1}$ é predominante e participa da regulação da secreção de saliva, especialmente na síntese e secreção de proteínas (LI et al., 2006). Em células acinares da parótida e de glândula submandibular de rato, a estimulação dos adrenoceptores $\beta$ promove o aumento de $A M P c$, levando à ativação da proteína quinase $A$ (PKA), que é responsável pela fosforilação da fosfoproteína integral de membrana de 26 kDa (pp26). A fosforilação da pp26 está relacionada ao processo de exocitose de grânulos secretórios (QUISSEL; BARZEN; DEISHER, 1993). Além disso, em células acinares da parótida, a PKA também promove a fosforilação de CREB (CAMP response element binding protein) que está envolvido na secreção de proteínas das células acinares (YAMADA et al., 2006).

\subsection{Adrenoceptores}

Os adrenoceptores pertencem à grande família de receptores acoplados à proteína G (GPCR), que constituem a maior família de proteínas presentes na 
superfície celular e estão envolvidos na transmissão de sinal (HERMANS, 2003). Mais de 1000 GPCRs tem sido identificados desde que o primeiro receptor foi clonado há mais de uma década e estas proteínas correspondem a mais de $1 \%$ do genoma total de mamíferos (KOLAKOWSKI, 1994; HERMANS, 2003). Os receptores GPCRs são proteínas que apresentam 7 domínios hidrofóbicos de estrutura $\alpha$ hélice, que atravessam a membrana plasmática sete vezes, sendo os segmentos interconectados por alças intracelulares e extracelulares, com a porção aminoterminal do lado extracelular e carboxi-terminal do lado intracelular (GETHER, 2000; HERMANS, 2003).

Características fisiológicas e estruturais foram utilizadas para classificar os GPCRs em um sistema denominado GRAFS, que contém cinco grandes famílias, Glutamato (G), Rodopsina (R), Adesão (A), Frizzled/Gustativo 2 (F) e secretina (S) (SCHIÖTH; FREDRIKSSON, 2005).

Os adrenoceptores pertencem à família Rodopsina. A família da rodopsina é a maior família dos GPCRs nos vertebrados. Baseando-se na investigação filogenética, a família de rodopsina foi dividida em 4 principais grupos $(\alpha, \beta, \gamma$ e $\delta)$ e em 13 subgrupos (FREDRIKSSON et al., 2003). O grupo $\alpha$ inclui os GPCRs de aminas, opsinas, melatonina e MECA (receptor de Melanocortina, de diferenciação Endotelial, de Canabinóide, de Adenosina) e de prostaglandinas. O grupo $\beta$ inclui somente os receptores de peptídeos tais como neuropeptídeo $\mathrm{Y}$ e colecistocinina. $\mathrm{O}$ grupo $\gamma$ inclui os receptores de SOG (receptor de Somatostatina, de Opióde e de Galanina), receptores de quimocinas e receptores de hormônio de concentração de melanina. $O$ grupo $\delta$ inclui receptores relacionados ao MAS (receptores oncogênicos), de glicoproteína, de purinas e olfatórios (FREDRIKSSON et al., 2003; SCHIÖTH; FREDRIKSSON, 2005).

Os adrenoceptores podem ser funcionalmente e estruturalmente divididos em três classes $\left(\alpha_{1}, \alpha_{2}, \beta\right)$. Estudos moleculares e farmacológicos identificaram três subtipos em cada classe $\left(\alpha_{1 \mathrm{~A}}, \alpha_{1 \mathrm{~B}}, \alpha_{1 \mathrm{D}}, \alpha_{2 \mathrm{~A}}, \alpha_{2 \mathrm{~B}}, \alpha_{2 \mathrm{C}}, \beta_{1}, \beta_{2}, \beta_{3}\right)$. Cada classe dos adrenoceptores está acoplada preferencialmente a um tipo de proteína G (MICHELOTTI; PRICE; SCHWINN, 2000; MINNEMAN, 2007).

A proteína $G$ heterotrimérica é composta de uma subunidade $\alpha$ que interage com o complexo $\beta \gamma$. A ativação do receptor promove a troca da molécula GDP pela molécula GTP dentro do sítio ativo da subunidade $\alpha$. A ligação da molécula GTP 
causa dissociação do complexo heterotrimérico, e ambos, GTP ligado à subunidade $\alpha$ e o complexo $\beta \gamma$, são capazes de interagir com efetores intracelulares ou de membrana. A atividade intrínseca da GTPase, presente na subunidade $\alpha$, causa hidrólise do GTP em GDP, restaurando a conformação inativa inicial e a afinidade ao complexo $\beta \gamma$ (HERMANS, 2003).

Classicamente, adrenoceptor $\alpha_{2}$ se acopla à proteína $G_{i}$, que promove a inibição da proteína adenilil ciclase diminuindo a produção de AMPc. O adrenoceptor $\alpha_{1}$ se acopla à proteína $G_{q / 11}$ que promove a ativação da proteína PLC $\beta$, que conseqüentemente leva à hidrólise de $\mathrm{PIP}_{2}$, produzindo $\mathrm{IP}_{3}$ e $\mathrm{DAG}$. $\mathrm{O}_{\mathrm{IP}_{3}}$ se acopla ao receptor de $\mathrm{IP}_{3}$ no retículo endoplasmático, promovendo a liberação do cálcio intracelular (MINNEMAN, 2007). O DAG serve como sinal para translocar a PKC para membrana plasmática e juntamente com o cálcio ativá-la (GARCÍA-SÁINZ; VÁZQUEZ-PRADO; MEDINA, 2000). Entretanto, diversas proteínas como PLC $\beta, \mathrm{IP}_{3}$, DAG, $\mathrm{Ca}^{+2}$ e PKC interagem com outras proteínas intracelulares, podendo estimular direta ou indiretamente a cascata das proteínas MAPKs (MARINISSEN; GUTKIND, 2001).

A MAPK é uma família de serina/treonina quinases que participa de eventos cruciais na via de transdução de sinais modulando a transcrição gênica. A cascata das MAPKs é evolutivamente conservada e presente em todos eucarióticos. Em mamíferos existem quatro grandes grupos de MAPKs: quinase regulada por sinal extracelular (ERK1/2), Jun N-terminal quinase (JNK), p-38 e ERK5. De maneira geral, ERK 1/2 é preferencialmente estimulada por mitógenos, enquanto JNK e p-38 são mais freqüentemente ativadas por estímulos ligados ao estresse ou citocinas inflamatórias (SCHAEFFER; WEBER, 1999; TANOUE; NISHIDA, 2003). A ERK5 é ativada preferencialmente por fatores de crescimento e por estímulos ligados ao estresse oxidativo e osmótico (TANOUE; NISHIDA, 2003). Entretanto, os quatro grupos de MAPKs podem desencadear respostas celulares tais como, proliferação, diferenciação, migração e apoptose (TURJANSKI; VAQUÉ; GUTKIND, 2007).

Trabalhos na literatura mostram que os adrenoceptores $\alpha_{1}$ ativam a via de ERK principalmente através da subunidade $\alpha$ da proteína $\mathrm{G}_{\mathrm{q}}$ (HAWES et al., 1995; GUTKIND, 1998). A estimulação da proteína $G_{q}$ aumenta a atividade de PLC $\beta$ levando a uma ativação de PKC, via DAG e Ca ${ }^{2+}$. PKC pode então, ativar proteínas tirosina quinases, como os receptores de fator de crescimento epitelial e a família de 
proteínas tirosina quinases, Src, que irão por sua vez ativar a cascata da MAPK, ERK 1/2 (KOSHIMUZU et al., 2003).

Em células PC12 transfectadas com os diferentes subtipos de adrenoceptor $\alpha_{1}$, foi demonstrado que a estimulação de $\alpha_{1 \mathrm{~A}}, \alpha_{1 \mathrm{~B}}$ e $\alpha_{1 \mathrm{D}}$ leva a um aumento na concentração de fosfato de inositol e $\mathrm{Ca}^{2+}$ citosólico, ativação de MAPK e de diferentes fatores de transcrição, porém com diferentes eficiências e diferentes respostas transcripcionais (ZHONG; HUME; KEEF, 2001).

Classicamente, o adrenoceptor $\beta$ se acopla à proteína $\mathrm{G}_{\mathrm{s}}$, que promove a ativação da proteína adenilil ciclase levando à produção de AMPc e, conseqüentemente, à ativação de PKA. Entretanto, quando ocorre a fosforilação do adrenoceptor $\beta$, este pode acoplar-se à proteína $G_{i} e$, com isso, ativar a PLC e fosfatidilinositol 3 quinase (PI3K) via subunidade $\mathrm{G}_{\beta \gamma}$ (UEZONO et al., 2004; XIAO et al., 2004). Em adição, a estimulação do adrenoceptor $\beta$ promove a ativação de diferentes vias da MAPKs. Em células PC12 foi demonstrado que o adrenoceptor $\beta$ ativa ERK 1/2 (WILLIAMS; ZHONG; MINNEMAN, 1998), enquanto em células musculares MF-2 DDT1, que expressam naturalmente o adrenoceptor $\beta$, levam a ativação JNK através da proteína Rho (YAMAUCHI et al., 2001). Zheng et al. (2000) também demonstraram que a estimulação do adrenoceptor $\beta$ promove ativação de p38 através de uma via dependente de PKA.

Portanto, as respostas celulares mediadas pelos receptores acoplados à proteína $\mathrm{G}$ não se limitam às vias clássicas de sistemas de segundos mensageiros, mas ao invés disso, resultam da integração funcional de um emaranhado de vias de sinalização intracelular (MARINISSEN; GUTKIND, 2001).

Trabalhos na literatura demonstram que os adrenoceptores $\alpha_{1}, \alpha_{2}$ e $\beta$ são também capazes de ativar o fator de transcrição NFKB em diferentes tipos celulares.

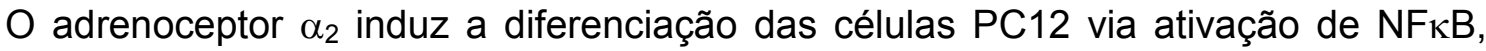
mas essa diferenciação depende do subtipo $\left(\alpha_{2 A}<\alpha_{2 B}<\alpha_{2 C}\right)$. A ativação de NFkB ocorre via proteína $\mathrm{PI} 3 \mathrm{~K}$ e a diferença da resposta dos diferentes subtipos é mediada via ERK1/2 (LYMPEROPOULOS et al., 2006). O adrenoceptor $\alpha_{1}$ participa da adaptação cardíaca que ocorre durante processos hemorrágicos através da ativação de NFKB (MELDRUM et al., 1997). Já a estimulação do adrenoceptor $\beta_{2}$ induz a expressão de interleucina-18 através da estimulação da proteína $G_{i}$ que ativa 
PI3K $\gamma, A k t / P K B$ e IKK (quinase de $I_{\kappa} B$ ), levando a ativação $N F \kappa B$ em células endoteliais cardíacas (CHANDRASEKAR et al., 2004).

O fator nuclear $\kappa B(N F \kappa B)$, foi caracterizado pela primeira vez por Sen $e$ Baltimore, (1986) e sua ativação pode ser induzida por uma variedade de fatores como estresse oxidativo, citocinas pró-inflamatórias, fatores de crescimento, vírus, produtos bacterianos e agonistas de receptores. Um experimento clássico realizado por Baeuerle e Baltimore, (1988) demonstrou que o NFКB está presente no citosol de células não estimuladas na forma inativa e quando as células são estimuladas promovem uma rápida translocação do NFผB para o núcleo.

NFkB é uma família de proteínas que podem formar complexos homodiméricos e heterodiméricos. Cinco proteínas foram identificadas em células de

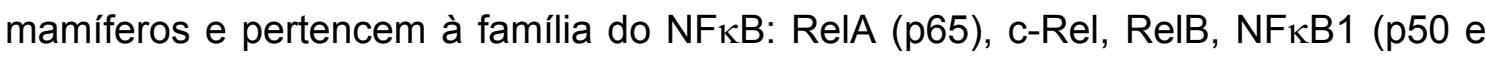
seu precursor p105) e NFкB2 (p52 e seu precursor p100). Estas proteínas possuem um domínio homólogo a Rel (RHD) altamente conservado, de 300 aminoácidos na região N-terminal, responsável pela ligação ao DNA, dimerização e associação com proteínas inibitórias IKB (GROSSMANN et al., 2000).

No estado inativo, o NFאB encontra-se no citoplasma associado à classe de proteínas inibitórias ( $\mid \kappa B s$ ). Sete $I \kappa B s$ foram identificadas: $I_{\kappa} B \alpha, I_{\kappa} B \beta, I \kappa B \varepsilon, I \kappa B \gamma$,

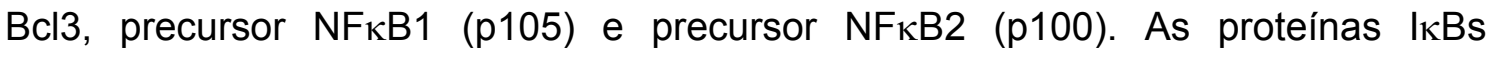
apresentam em comum um domínio de seis ou sete repetições de anquirina, que é importante na interação proteína-proteína, ou seja, na interação com NFkB, mantendo-o no citoplasma, mascarando assim a seqüência de localização nuclear (NLS), situada na região C-terminal do domínio RHD nuclear (WHITESIDE; ISRAËL, 1997). Diferentes mecanismos de ação dos membros da família do I $\mathrm{B}$ aumentam a complexidade de ativação do NFкB (TAM; SEN, 2001).

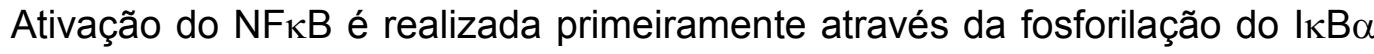
na serina 32 e serina 36, e do IאB $\beta$ na serina 19 e serina 23 (HAYDEN; GHOSH, 2004). A proteína $I_{\kappa} B$ fosforilada recebe a adição de ubiquitinas, através da ação da ubiquitina ligase, sendo em seguida degradada pelo complexo proteassoma 26S. Esta proteólise resulta na liberação do NFאB e sua translocação para o núcleo, onde regulam a expressão de genes alvos (Figura 5) (CHEN; GREENE, 2004; WESTWINCK; SCHWAMBORN; MERCURIO, 2004). 
Outras duas vias atípicas de ativação do NFkB foram descritas. A primeira via atípica foi observada como resultado da hipóxia ou da utilização do inibidor de tirosina fosfatase, pervanadato, indicando que a ativação de $N F \kappa B$ ocorre pela fosforilação da tirosina 42 do IKB $\alpha$ (KARIN; BEN-NERIAH, 2000). A identidade da proteína tirosina quinase envolvida nesta via não é conhecida, mas dados na literatura sugerem que alguns membros da família Src são responsáveis pela

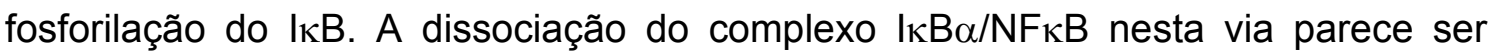
mediada pela interação com $\mathrm{PI3K}$ e não pela degradação proteassômica $26 \mathrm{~S}$ (BERAUD; HENZEL; BAEUERLE, 1999; KARIN; BEN-NERIAH, 2000; WHITESIDE; ISRAËL, 1997). A segunda via atípica foi observada em células expostas à radiação

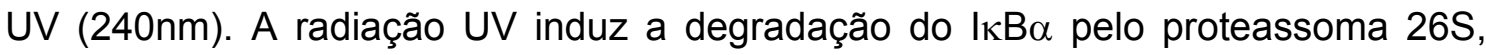
mas este processo não é mediado pela fosforilação das serinas 32,36 ou pela tirosina 42. O mecanismo de degradação do $I_{\kappa} B \alpha$ é desconhecido. Ambas as vias atípicas de ativação do $\mathrm{NF \kappa B}$, são consideradas mais lentas e fracas do que em comparação com a via de ativação clássica (KARIN; BEN-NERIAH, 2000). 


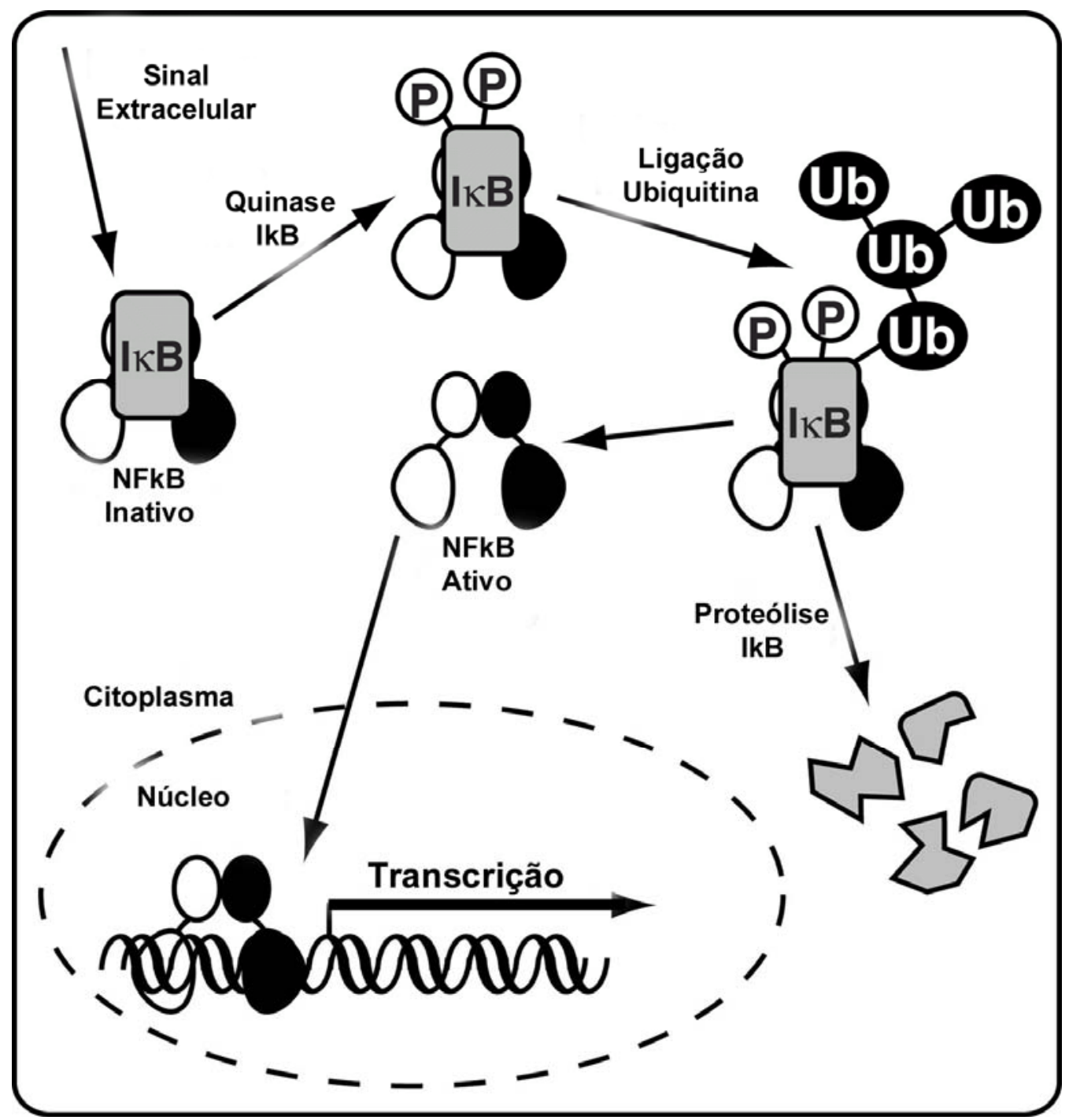

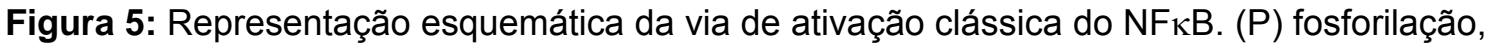
(Ub) ubiquitina. (adaptado de HUXFORD, 2007).

A ativação de adrenoceptores $\alpha$ e $\beta$ também induz a expressão de c-Fos e cJun em uma variedade de células como em cardiomiócitos (IWAKI et al., 1990; TAIMOR et al., 2004), neuroblastomas (SHILLING et al., 1991), células do músculo liso vascular (OKAZAKI et al., 1994), adipócitos (THONBERG et al., 1994) e hepatócios (GARCIA-SÁINZ; ALCÁNTARA-HERNÁNDEZ, 1996; IM et al., 1998). Estudos realizados por Garcia-Sáinz; Alcántara-Hernández; Vázquez-Prado (1998) mostraram que os três subtipos do adrenoceptor $\alpha_{1}$ quando ativados podem aumentar a expressão dos genes c-fos e c-jun, porém a eficácia da expressão varia 
de acordo com o subtipo, sendo este efeito dependente de PKC. Outro estudo também mostrou que a estimulação do adrenoceptor $\alpha$ ativa AP-1 e estimula a síntese protéica, levando à hipertrofia de cardiomiócitos (TAIMOR et al., 2004). O adrenoceptor $\beta$ quando estimulado, também induz a expressão do gene c-fos em glândulas submandibulares de camundongos (BARKA; GUBITS; VAN DER NOEN, 1986) e de c-fos e c-jun em hepatócitos (IM et al., 1998).

A família do fator de transcrição AP-1 é formada pela associação homodimérica ou heterodimérica de membros da família das proteínas Jun (c-Jun, JunB e JunD), Fos (c-Fos, FosB, Fra-1 e Fra-2) e ATF (ATFa, ATF-2 e ATF-3). As subunidades do AP-1 são compostas por uma região de ligação ao DNA (domínio DBD) e uma segunda região de ativação transcripcional (domínio de transativação). O domínio DBD da proteína AP-1 também é conhecido como região bZip, e pode ser dividida em dois domínios: domínios básicos, compostos por aminoácidos básicos e responsáveis pelo contato com DNA $(b)$, domínio leucine zipper, caracterizado por sete repetições de leucina formando uma estrutura responsável pela dimerização (Zip) (KARIN; LIU; ZANDI, 1997; ANGEL, 2004).

Os genes jun e fos representam um protótipo da classe dos genes de ativação imediata que são caracterizados por uma rápida e transiente ativação da transcrição em resposta a diversas condições, como fatores de crescimento, citocinas, promotores de tumor, carcinógenos e expressão de certos oncogenes (MECHTA-GRIGORIOU; GERALD; YANIV, 2001).

A atividade do AP-1 é regulada pela interação com proteínas quinases específicas como glicogênio sintase quinase (GSK3) e caseína quinase II (CK-II), quinase reguladora de Fos (FRK), proteínas da família da MAPK, como as quinases ERK1 e ERK2, JNK-1, JNK-2 e JNK-3 ou por co-ativadores transcripcionais como JAB1 (proteína 1 ligada ao domínio de ativação Jun) e p202. A fosforilação do domínio DBD por estas quinases diminui a ligação ao DNA, e a desfosforilação pode aumentar a ligação ao DNA (KARIN, 1995; KARIN; LIU; ZANDI, 1997; ANGEL, 2004) 


\subsection{Relevância}

Uma vez que a ativação da inervação noradrenérgica pela extração de veneno desencadeia o ciclo de produção de veneno na glândula de veneno através da estimulação dos adrenoceptores $\alpha$ e $\beta$, tornou-se interessante verificar se esses receptores que desencadeiam uma complexa sinalização intracelular ativariam fatores de transcrição, tais como o NFאB e AP-1. A ativação desses fatores de transcrição poderia ter um papel fundamental na expressão de toxinas do veneno, bem como de proteínas da glândula de veneno essenciais para sua ativação.

A compreensão dos mecanismos celulares envolvidos no desencadeamento do ciclo de produção e secreção de veneno da glândula da serpente Bothrops jararaca é de grande importância para estabelecer uma linhagem de células secretoras funcionais que secretem veneno para o meio.

Além disso, devido as suas características peculiares como estados de quiescência e ativado distintos e um longo ciclo de veneno, a glândula de veneno de serpente Viperidae é um excelente modelo para o estudo dos mecanismos que regulam a síntese de proteínas em glândulas exócrinas. 
2 Objetives 
Identificar os mecanismos pelos quais a inervação noradrenérgica desencadeia o ciclo de produção de veneno em glândulas de veneno da serpente Bothrops jararaca.

Estratégias:

- Verificar através de ensaios in vivo e in vitro se noradrenalina é capaz de ativar fatores de transcrição como NFкB e AP-1 em glândula de veneno;

- Verificar se a estimulação dos adrenoceptores $\alpha$ e $\beta$ participa diretamente da síntese de proteínas do veneno;

- Analisar a importância da inervação noradrenérgica para a ativação da glândula de veneno. 


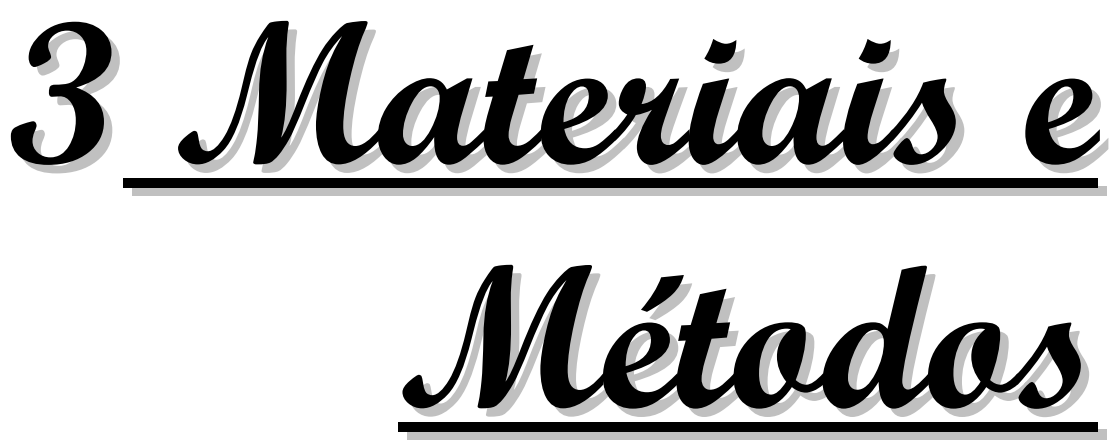




\subsection{Tampões e Soluções}

- Solução Fisiológica Krebs-Hepes: $\mathrm{NaCl} 120$ mM; KCl 4 mM; $\mathrm{MgSO}_{4} 1,2$ $\mathrm{mM} ; \mathrm{KH}_{2} \mathrm{PO}_{4}$ 1,2 mM; HEPES 15 mM e glicose 10 mM, pH 7,4.

- Solução Corante azul: Comassie blue R 0,1\% em ácido acético $5 \%$ e metanol $25 \%$.

- Solução Descorante: ácido acético 5\% e metanol 25\%.

- Tampão de Amostra (2X - SDS-PAGE): SDS 4\%; glicerol 20\%; $\beta$ Mercaptoetanol 10\%; Tris 50 mM, pH 6,8; azul de Bromofenol 0,05\%.

- Tampão TBE (10X): Tris base 0,4 M; ácido bórico 0,4 M; EDTA 5mM.

- Tampão de Corrida (SDS-PAGE): Tris 25 mM; glicina 192 mM; SDS 0,1\%.

- Tampão de Corrida (gel de retardo): TBE $(0,5 X)$.

- Tampão de Carregamento (gel de retardo): Tris $\mathrm{HCl} 250$ mM, pH 7,5; glicerol 40\%; azul de bromofenol 0,2\%.

- $\quad$ Tampão de Ligação (gel de retardo): $\mathrm{MgCl}_{2} 1$ mM, EDTA 0,5 mM, pH 8,0; DTT 0,5 mM; NaCl 50 mM; Tris $\mathrm{HCl} 10$ mM, pH 7,5; glicerol 0,4\%.

- $\quad$ Tampão de Extração Nuclear: HEPES 10 mM, pH 7,5; KCl 0,5 M; EDTA 1 $\mathrm{mM}, \mathrm{pH} 8,0$; glicerol 10\%; DTT $1 \mathrm{mM}$; coquetel de inibidores de protease diluição 1:100.

- $\quad$ Tampão de Lise: HEPES 10 mM, pH 7,5; KCl 10 mM; EDTA 0,1 mM; pH 8,0; glicerol 10\%; DTT 1 mM; coquetel de inibidores de protease diluição 1:100.

- $\quad$ Tampão PBS: $\mathrm{NaH}_{2} \mathrm{PO}_{4} \cdot \mathrm{H}_{2} \mathrm{O} 1,5$ mM; $\mathrm{Na}_{2} \mathrm{HPO}_{4} 8$ mM; $\mathrm{NaCl} 140$ mM.

\subsection{Drogas e Reagentes}

- $\quad$ ATP $\gamma \mathrm{P}^{32}$ : GE Healthcare, Buckinghamshire, UK

- $\quad$ Azul de Tripan 0,4\%: Gibco BRL, Rockville, MD, USA

- Azul de Bromofenol: Plus One, Uppsala, Sweden

- $\quad$ Azul de Comassie Brilliant R: Sigma-Aldrich, St. Louis, MO, USA

- Bio-Rad protein assay: Bio Rad Lab., Hercules, CA, USA 
- $\quad$ Bitartarato de $( \pm)$ - Arterenol (Noradrenalina): Sigma-Aldrich, St. Louis, MO, USA

- $\quad \beta$-Mercaptoetanol Molecular Biology Grade: Calbiochem, La Jolla, CA, USA

- Colagenase: Worthington Biochem. Co., Lakewood, NJ, USA

- Colunas de resina: G-25 MicroSpin, GE Healthcare, Buckinghamshire, UK

- $\quad$ Coquetel inibidor de protease: P 8340, Sigma-Aldrich, St. Louis, MO, USA

- $\quad$ Filme para auto-radiografias: BioMax-AR, Kodak Co., Rochester, NY, USA

- $\quad$ Filtro de nylon 70 $\mu \mathrm{m}$ : BD Biosciences, Bedford, MA, USA

- $\quad$ Fixador para revelação manual: GBX Fixer, Kodak Co., Rochester, NY, USA

- Hialuronidase: Sigma-Aldrich, St. Louis, MO, USA

- Hidrocloreto de L-fenilefrina: Sigma-Aldrich, St. Louis, MO, USA

- Líquido de cintilação: EcoLume, ICN Biomedicals Inc.,Costa Mesa, CA, USA

- $\quad$ Nonidet P-40 (NP40): Calbiochem, La Jolla, CA, USA

- Oligonucleotídeos NF-kappaB Consensus e AP-1 Consensus: Promega, Co., Madison, WI, USA

- $\quad$ Ortovanadato de sódio: MP Biomedicals, LLC, Aurora, OH, USA

- Padrão de peso molecular: SDS-PAGE molecular Weight Standarts, Low Range, Bio Rad Lab., Hercules, CA, USA

- Pentobarbital sódico: Cristália, São Paulo, SP, Brasil

- Poly (dl-dC): GE Healthcare, Buckinghamshire, UK

- Reserpina cristalina: Sigma-Aldrich, St. Louis, MO, USA

- Revelador para revelação manual: GBX developer, Kodak Co., Rochester, NY, USA

- $\quad$ T4 polinucleotídeo quinase: Invitrogen Co., Carlsbad, CA, USA

Todos os demais sais e reagentes utilizados para preparação de tampões foram provenientes da MERCK (Alemanha) ou Sigma-Aldrich, St. Louis (USA). 


\subsection{Animais}

Serpentes Bothrops jararaca (WIED, 1824), N=74, adultas (100 - $400 \mathrm{~g}) \mathrm{de}$ ambos os sexos (Figura 2), classificadas no Laboratório de Herpetologia do Instituto Butantan, foram tratadas segundo Breno et al. (1990) e mantidas em sala com condições ambientais controladas: fotoperíodo de 12 horas, temperatura entre $21^{\circ} \mathrm{C}$ e $27^{\circ} \mathrm{C}$ e umidade relativa de aproximadamente $65 \%$. Os procedimentos experimentais estão de acordo com o Colégio Brasileiro de Experimentação Animal (COBEA) e foram aprovados pela Comissão de Ética no Uso de Animais do Instituto Butantan (CEUAIB) e pela Comissão de Ética em Experimentação Animal do Instituto de Ciências Biomédicas da Universidade de São Paulo.

\subsection{Glândulas de veneno}

Foram utilizadas glândulas de veneno de serpentes que não sofreram extração de veneno (quiescente), que sofreram extração manual de veneno 30, 60 e 120 minutos ou 4, 7 e 15 dias antes de serem sacrificadas.

As serpentes foram previamente anestesiadas com pentobarbital sódico (30 $\mathrm{mg} / \mathrm{kg}$, s.c.) e após uma hora, as serpentes foram sacrificadas por decapitação e o par de glândulas de veneno coletadas e dissecadas segundo Yamanouye et al. (2007). As extrações manuais de veneno foram realizadas de acordo com Belluomini (1968).

\subsection{Dispersão de células secretoras da glândula de veneno}

A dispersão das células secretoras foi baseada no método descrito por Kerchove et al. (2004) e Yamanouye et al. (2007). Resumidamente, as glândulas de veneno foram removidas e cortadas em fatias de $250 \mu \mathrm{m}$ (Mcllwain Tissue Chopper, Vibratome Company, Midpoint Drive, O'Fallon, MO). Estas fatias foram colocadas em $30 \mathrm{ml}$ de solução fisiológica de Krebs-Hepes contendo colagenase (3,0 U/mg de 
tecido úmido) e hialuronidase (3,5 U/mg de tecido úmido). Após uma hora e meia de digestão enzimática sob agitação orbital constante, auxiliada por dispersão mecânica (sucessivas pipetagens), as células foram centrifugadas (10 minutos a 1.000 g) e ressuspensas em solução fisiológica Krebs-Hepes. Após nova centrifugação e ressuspensão para assegurar total remoção das enzimas, as células foram filtradas em malha de nylon de $70 \mu \mathrm{m}$ para separá-las do tecido conjuntivo adjacente, e foram novamente centrifugadas e ressuspensas em solução fisiológica Krebs-Hepes contendo 2,5 mM de $\mathrm{CaCl}_{2}, 0,1 \mathrm{~g} / \mathrm{l}$ de ácido ascórbico A contagem das células foi realizada na presença de azul de tripan (solução de 0,4\%) e as células dispersas viáveis foram utilizadas em experimentos imediatamente após a dispersão.

\subsection{Extrato total de glândula de veneno}

Os extratos de glândulas de veneno foram preparados de acordo com Gonçalves et al. (1997). Resumidamente, as glândulas de veneno foram cortadas em fatias de $250 \mu \mathrm{m}$ (Mcllwain Tissue Chopper, Vibratome Company, Midpoint Drive, O'Fallon, MO), homogenizadas (Tissue homogenizer, Thomas Teflon pestle, Swedesboro, NJ, US) (15g/100 ml) em solução de sacarose 0,32 M contendo EDTA $1 \mathrm{mM}, \mathrm{MgCl}_{2} 3 \mathrm{mM}$ e coquetel de inibidores de proteases (diluição 1:100) e centrifugadas a $14.000 \mathrm{~g}$ por $40 \mathrm{~min}$. O sobrenadante foi removido e congelado a $20{ }^{\circ} \mathrm{C}$ para posterior análise das proteínas.

\subsection{Extratos nucleares de glândula de veneno e de células secretoras dispersas}

Os extratos nucleares foram preparados como descrito por Rong e Baudry (1996) com modificações padronizadas para extratos de glândulas de veneno e células secretoras dispersas. Resumidamente, as glândulas de veneno foram dissecadas, homogeneizadas, no gelo, em tampão de lise $(2,6 \mu \mathrm{l} / \mathrm{mg}$ de tecido 
úmido) utilizando um homogenizador Dounce (Tissue homogenizer, Thomas Teflon pestle, Swedesboro, NJ, US) e foram incubadas no gelo por 15 minutos. Após incubação, $0,6 \%$ de Nonidet P-40 foi acrescentado à mistura e agitada vigorosamente no vortex por $10 \mathrm{~s}$ e centrifugada $\left(12.000 \mathrm{~g}, 2\right.$ minutos, $\left.4{ }^{\circ} \mathrm{C}\right)$. Os sobrenadantes foram descartados. Os precipitados nucleares foram lavados com $150 \mu$ tampão de lise, centrifugados novamente, ressuspensos em tampão de extração nuclear $(0,7 \mu \mathrm{l} / \mathrm{mg}$ de tecido úmido), incubados no gelo por $15 \mathrm{~min}$. e centrifugados ( $13.000 \mathrm{~g}, 20$ minutos, $\left.4{ }^{\circ} \mathrm{C}\right)$. Os sobrenadantes contendo proteínas nucleares foram aliquotados e estocados $-70^{\circ} \mathrm{C}$ até o uso.

Para o preparo do extrato nuclear de células dispersas, 2 a $3 \times 10^{6}$ células secretoras foram colocadas em $400 \mu$ tampão de lise gelado e o rompimento celular foi realizado através de pipetagens sucessivas. Após a incubação, $25 \mu \mathrm{l}$ da solução $10 \%$ de nonidet P-40 foi acrescentada à mistura. O procedimento a seguir segue 0 do extrato nuclear da glândula de veneno, sendo que a etapa de lavagem com tampão de lise foi omitida e o precipitado nuclear ressuspenso em $100 \mu \mathrm{l}$ de tampão de extração nuclear.

\subsection{Eletroforese em gel de poliacrilamida na presença de SDS (SDS-PAGE)}

As proteínas dos venenos (10 $\mu \mathrm{g}$ de proteína) ou dos extratos totais de glândula de veneno (30 $\mu \mathrm{g}$ de proteína) foram desnaturadas em tampão de amostra em condições redutoras, completamente dissociadas em banho-maria fervente durante 5 minutos e submetidas à eletroforese em gel de poliacrilamida (12\% ou 15\%) na presença de SDS, segundo método descrito por Laemmli (1970), utilizando o aparelho Mini - PROTEAN II cell (Bio-Rad, Hercules, CA, USA). As proteínas foram coradas com Comassie blue $1 \%$.

\subsection{Determinação de proteína}

A concentração de proteína dos venenos, dos extratos totais e nucleares das glândulas de veneno foi determinada, pelo método de Bradford (1976), utilizando 
albumina de soro fetal bovino como padrão e reagente Bio-Rad assay protein. A absorbância foi lida em 620 nm, no fotômetro Multiskan EX (Thermo Scientific, Waltham, MA, USA).

\subsection{Ensaio de gel de retardo para NFKB e AP-1}

Este ensaio consiste na reação de ligação de proteínas do extrato nuclear com uma seqüência de nucleotídeos específica para o fator de transcrição NFKB (5'AGTTGAGGGGACTTTCCCAGGC-3') ou AP-1 (5'CGCTTGATGAGTCAGCCGGAA-3'), sendo estas previamente marcadas com $\gamma_{-}{ }^{32} \mathrm{P}-$ ATP (atividade específica $3.000 \mathrm{Ci} / \mathrm{mmol}$ ) através da $\mathrm{T}_{4}$ polinucleotídeo quinase $\left(37^{\circ} \mathrm{C}, 10 \mathrm{~min}\right.$., de acordo com as instruções do fabricante). Os oligonucleotídeos não marcados foram removidos através da utilização da coluna Microspin G25. O gel de retardo foi realizado como descrito por Staal et al. (1990) com algumas modificações padronizadas para glândulas de veneno e células secretoras. 7-10 $\mu \mathrm{g}$ de proteína nuclear ou $15 \mu$ do extrato nuclear de células secretoras foram incubados com tampão de ligação contendo $1 \mu \mathrm{g}$ de poli (dl-dC) para um volume final de $20 \mu \mathrm{l}$, por $20 \mathrm{~min}$ em temperatura ambiente. Cada amostra foi então incubada com 20.000-50.000 cpm de oligonucleotídeo marcado por $30 \mathrm{~min}$ em temperatura ambiente. Nos ensaios de competição, foi adicionado o dobro de oligonucleotídeo não marcado, 20 min antes da adição da sonda marcada. O meio reacional foi submetido a uma eletroforese em gel de poliacrilamida nãodesnaturante $6 \%$ em tampão Tris-borato/EDTA a $150 \mathrm{~V}$ por 1,5 horas em temperatura ambiente. O gel foi seco e exposto no filme BioMax XAR à $-70^{\circ} \mathrm{C}$ durante 4 a 7 dias, dependendo da marcação da sonda.

\subsection{Densitometria}

A densidade de cada banda obtida nas auto-radiografias dos ensaios de gel de retardo foram digitalizadas e analisadas com auxílio do software M4 image 
analysis (MCID, Ontario, Canada). Os valores da densitometria das bandas dos extratos nucleares de glândulas de veneno ativadas por extração de veneno por 30, 60 ou $120 \mathrm{~min}$. ou de células secretoras estimuladas por agonistas foram expressos como porcentagem em relação ao basal (glândula ou célula quiescente). Em relação às células secretoras dispersas, os dados foram normalizados para $1 \times 10^{6}$ células.

A densidade de cada banda obtida na eletroforese em gel de poliacrilamida na presença de SDS foi quantificada através do software Quantity One (Bio-Rad, Hercules, CA, USA).

\subsection{Protocolo experimental}

\subsubsection{Determinação de fatores de transcrição NFkB e AP-1 na glândula de veneno}

\subsubsection{Estudo in vivo: Extração de veneno na ativação de fatores de transcrição}

Os extratos nucleares foram preparados a partir de glândulas de veneno de serpentes machos ou fêmeas que não sofreram extração de veneno (quiescentes) ou que sofreram extração de veneno 30,60 e 120 minutos antes do sacrifício. A ativação de fatores de transcrição foi avaliada através do ensaio de gel de retardo.

\subsubsection{Estudo in vitro: Estimulação dos adrenoceptores $\alpha$ e $\beta$ na ativação dos fatores de transcrição}

Extratos nucleares foram preparados a partir de células secretoras dispersas (2 a $3 \times 10^{6}$ ) de glândulas de veneno em estado quiescente obtidas de serpentes fêmeas e estimuladas com noradrenalina $\left(10^{-4} \mathrm{M}\right)$, fenilefrina $\left(3.10^{-4} \mathrm{M}\right)$ ou isoprenalina $\left(3.10^{-4} \mathrm{M}\right)$ durante 30 ou 60 minutos. A ativação de fatores de transcrição foi analisada no ensaio de gel de retardo e os resultados foram normalizados para $1 \times 10^{6}$ células. 


\subsubsection{Participação dos adrenoceptores $\alpha$ e $\beta$ na síntese de proteínas}

\subsubsection{Veneno}

Para verificar a importância da estimulação dos adrenoceptores na produção de toxinas do veneno, as serpentes foram tratadas com reserpina ( $20 \mathrm{mg} / \mathrm{kg}$, s.c., 24 horas antes da extração de veneno, seguido por injeções diárias de $5 \mathrm{mg} / \mathrm{kg}$, s.c. por 15 dias) com o intuito de depletar os estoques de noradrenalina (YAMANOUYE et al., 1997). Algumas serpentes tratadas com reserpina receberam uma dose de fenilefrina (100 mg/kg, s.c.) outras de isoprenalina (100 mg/kg, s.c.) logo após a extração de veneno, necessário para o desencadeamento do ciclo de produção de veneno (KERCHOVE et al, 2004; KERCHOVE, 2005; ZABLITH, 2007; NUNEZBUGOS et al., 1993). A segunda amostra de veneno foi coletada 15 dias após a primeira. Devido à variabilidade individual do veneno (MEIER, 1986; CHIPPAUX et al., 1991; MONTEIRO et al., 1998a; MONTEIRO et al., 1998b) a composição protéica da segunda amostra foi comparada com a primeira amostra, em SDSPAGE. Como controle, duas coletas de veneno foram realizadas de serpentes não tratadas, em intervalo de 15 dias.

\subsubsection{Glândula de veneno}

\subsection{Análise do perfil protéico da glândula de veneno durante o ciclo de produção de veneno}

Foram realizados extratos totais da glândula de veneno de serpentes machos ou fêmeas que não sofreram extração de veneno (quiescente) ou que sofreram extração 4, 7, e 15 dias antes de serem sacrificadas. As proteínas das glândulas de veneno foram analisadas em SDS-PAGE. 


\subsection{Efeito da estimulação dos adrenoceptores na composição protéica da}

glândula de veneno

Foram realizados extratos totais de glândula de veneno de serpentes fêmeas ou machos que sofreram extração 4 ou 7 dias antes do sacrifício, respectivamente (controle) ou de serpentes tratadas com reserpina $(20 \mathrm{mg} / \mathrm{kg}$, s.c., 24 horas antes da extração de veneno, seguido por injeções diárias de $5 \mathrm{mg} / \mathrm{kg}$, s.c. por 4 dias nas fêmeas ou 7 dias nos machos). Algumas serpentes tratadas com reserpina receberam uma dose de fenilefrina (100 mg/kg, s.c.), outras de isoprenalina (100 $\mathrm{mg} / \mathrm{kg}$, s.c) ou ambas logo após a primeira extração de veneno. As glândulas de veneno de serpentes fêmeas foram removidas 4 dias e dos machos removidas 7 dias após a extração de veneno. Os extratos totais foram analisados por SDSPAGE.

\subsection{Análise estatística}

Os resultados apresentados foram expressos como Média \pm EPM. A diferença estatística entre mais de duas médias foram analisadas pelo teste de variância ANOVA seguido pelo teste de Newman-Keuls. O nível de significância aceito foi de $5 \%(P<0,05)$. 
4 Resultadas 


\subsection{Extração de veneno aumenta ativação de NFkB em células secretoras da glândula de veneno da Bothrops jararaca}

A extração manual de veneno ativa as células secretoras a produzirem veneno e essa ativação é acompanhada por mudanças morfológicas e bioquímicas (BEN-SHAUL; LIFSHITZ; KOCHVA, 1971; ROTENBERG; BAMBERGER; KOCHVA, 1971; ZAGO, 1971; SCHAEFFER et al., 1972a, SCHAEFFER et al., 1972b; ORON; BDOLAH, 1973; KOCHVA, 1978; BDOLAH, 1979, CARNEIRO et al., 1991; MACKESSY, 1991; SALOMÃO, 1991). Portanto, fomos verificar se a extração de veneno poderia ativar fatores de transcrição.

Foi verificado, através de ensaios de gel de retardo, a presença de $\mathrm{NF} \kappa \mathrm{B}$ e AP-1 ativados em extratos nucleares de células secretoras quiescentes da glândula de veneno da serpente Bothrops jararaca (Figura 6A). A especificidade da ligação do oligonucleotídeo marcado com as proteínas do extrato nuclear foi confirmada através de ensaios de competição, onde o dobro de oligonucleotídeo não marcado foi adicionado (Figura 6A).

A extração de veneno foi capaz de aumentar a ativação do NFkB na glândula de veneno nos diferentes tempos de ativação avaliados, sendo estes 30, 60 e 120 minutos após a extração de veneno. Como mostram as figuras $6 \mathrm{~A}$ e B, a ativação de NFאB está aumentada em extratos nucleares de glândula de veneno $30(33,21 \pm$ $7,16, n=5$ e $16,43 \pm 6,8, n=4), 60(16,21 \pm 3,83, n=5$ e $38,86 \pm 9,61, n=4)$ e 120 $(12,67 \pm 4,8, n=5$ e $11,54 \pm 2,09, n=4)$ minutos após a extração de veneno em serpentes fêmeas e machos respectivamente (Tabela 1). O pico máximo de ativação alcançado nas serpentes fêmea ocorreu 30 minutos após a extração de veneno e no macho ocorreu 60 minutos após a extração de veneno (Figura 6B).

A extração de veneno também foi capaz de aumentar a ativação de AP-1 na glândula de veneno nos diferentes tempos de ativação avaliados, sendo estes 30, 60 e 120 minutos após a extração de veneno. Como mostram as figuras $7 \mathrm{~A}$, $\mathrm{B}$ e $\mathrm{C}$, a ativação de AP-1 está aumentada nos extratos nucleares da glândula de veneno 30 $(12,51 \pm 7,85, n=4$ e 15,04 $\pm 7,05, n=5), 60(91,96 \pm 25,65, n=4$ e 56,07 $\pm 14,96$, $n=5)$ e $120(42,67 \pm 18,89, n=4$ e $31,08 \pm 9,67, n=5)$ minutos após a extração de veneno em serpentes fêmeas e machos respectivamente (Tabela 1). O pico máximo de ativação do AP-1 para ambas as serpentes fêmeas e machos ocorreu 60 minutos 
após a extração de veneno. No entanto, a ativação de AP-1 nas fêmeas é significativamente maior em relação aos machos $(p<0,05)$ (Figura $7 C)$. .

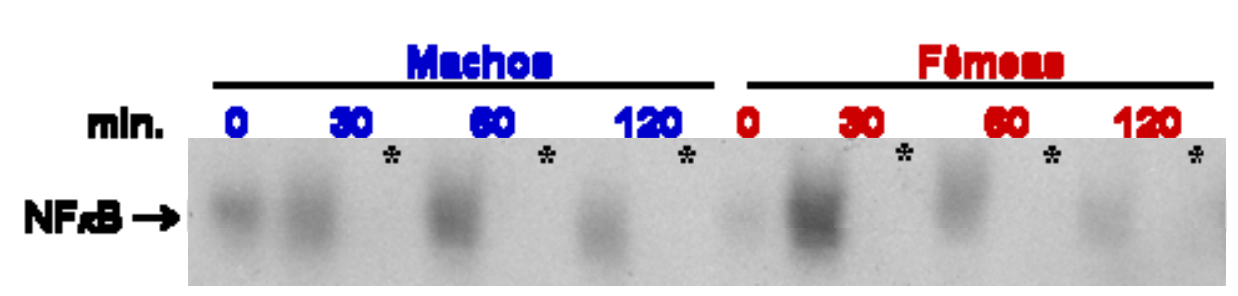

A

B

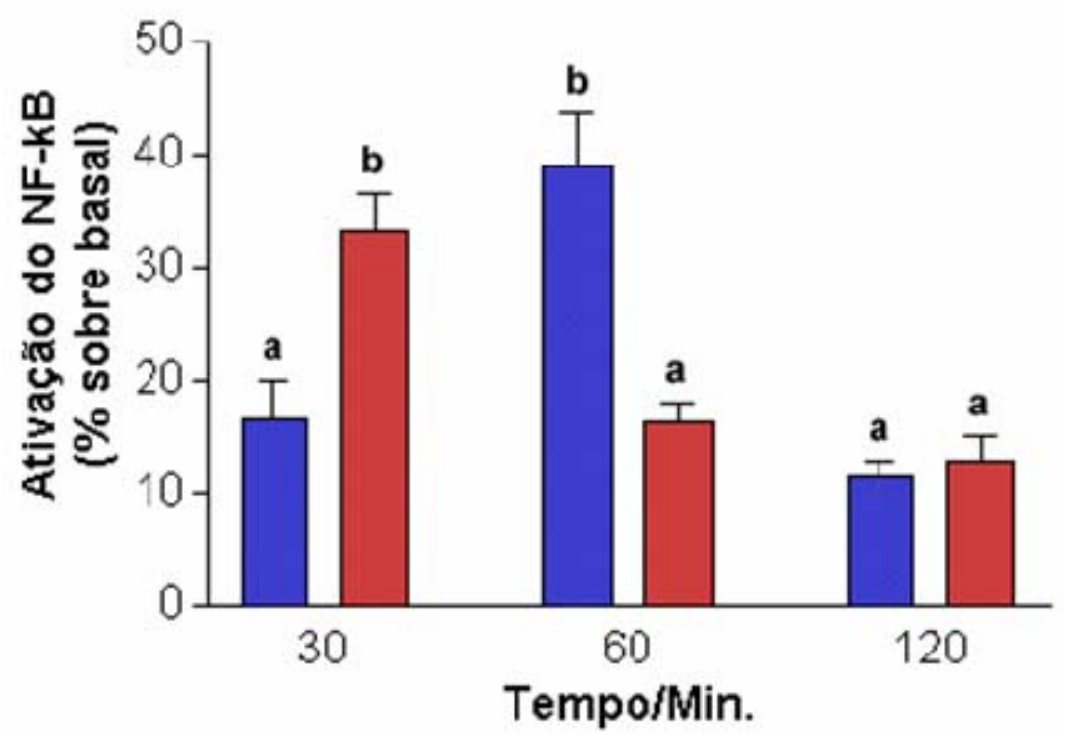

Figura 6: Decurso temporal da ativação do $N F \kappa B$ promovida pela extração de veneno em glândulas de veneno da serpente Bothrops jararaca. (A) Ensaio de gel de retardo representativo de extratos nucleares de glândulas de veneno de serpentes machos e fêmeas no estágio quiescente (0, basal), 30, 60 e 120 minutos após a extração de veneno. * Ensaios de competição realizado usando um excesso do

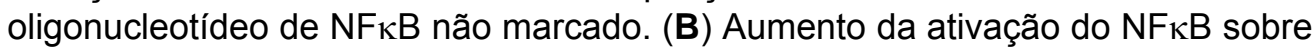
basal mensurado por densitometria dos géis de retardo dos extratos nucleares de glândulas de veneno 30, 60 e 120 minutos após a extração de veneno. Notar o dimorfismo sexual na ativação do NFKB. Letras diferentes indicam diferenças significativas (ANOVA - Newman-Keuls, $p<0.05$ ). 

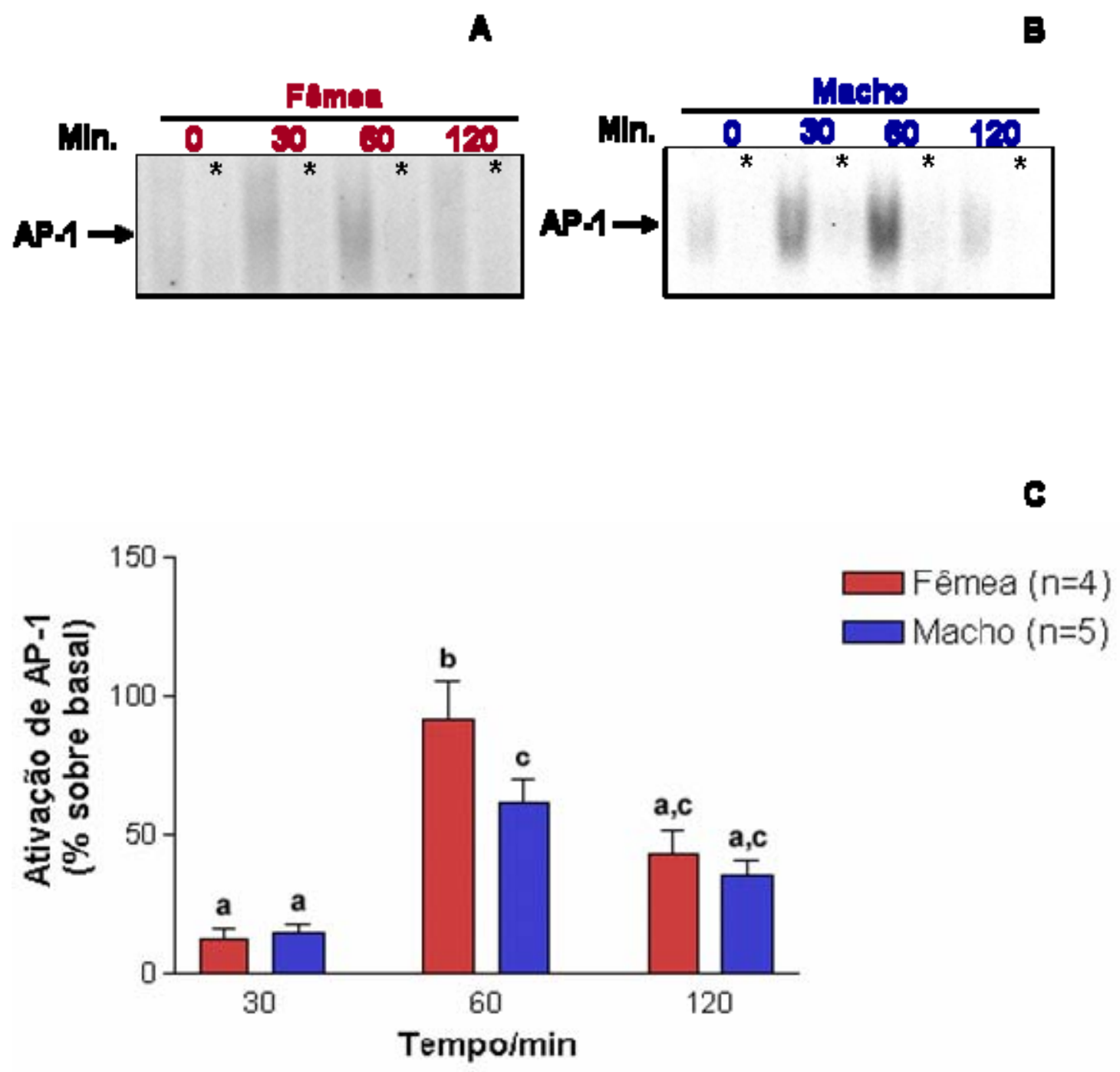

Figura 7: Decurso temporal da ativação do AP-1 promovida pela extração de veneno em glândulas de veneno da serpente Bothrops jararaca. Ensaio de gel de retardo representativo de extratos nucleares de glândulas de veneno de serpentes fêmeas (A) e machos (B) nos estágios quiescente (0, basal), 30, 60 e 120 minutos após a extração de veneno. * Ensaios de competição realizado usando um excesso do oligonucleotídeo de AP-1 não marcado. (C) Aumento da ativação do AP-1 sobre o basal mensurado por densitometria dos géis de retardo dos extratos nucleares de glândulas de veneno 30,60 e 120 minutos após a extração do veneno. Letras diferentes indicam diferenças significativas (ANOVA Newman-Keuls, $p<0.05)$. 
Tabela 1 - Aumento da ativação do NFкB e AP-1 após a extração de veneno em glândula de veneno da serpente Bothrops jararaca.

\begin{tabular}{|c|c|c|c|c|}
\hline & \multicolumn{2}{|c|}{$\mathrm{NF}_{\kappa \mathrm{B}}$} & \multicolumn{2}{|c|}{ AP-1 } \\
\hline Tempo/minutos & Fêmeas & Machos & Fêmeas & Machos \\
\hline 30 & $\begin{array}{c}33,21 \pm 7,16^{b} \\
(n=5)\end{array}$ & $\begin{array}{c}16,43 \pm 6,8^{a} \\
(n=4)\end{array}$ & $\begin{array}{c}12,51 \pm 7,85^{a} \\
(n=4)\end{array}$ & $\begin{array}{c}15,04 \pm 7,05^{a} \\
(n=5)\end{array}$ \\
\hline 60 & $\begin{array}{c}16,21 \pm 3,83^{a} \\
(n=5)\end{array}$ & $\begin{array}{c}38,86 \pm 9,61^{b} \\
(n=4)\end{array}$ & $\begin{array}{c}91,96 \pm 25,65^{b} \\
(n=4)\end{array}$ & $\begin{array}{c}56,07 \pm 14,96^{\mathrm{c}} \\
(\mathrm{n}=5)\end{array}$ \\
\hline 120 & $\begin{array}{c}12,67 \pm 4,80^{a} \\
(n=5)\end{array}$ & $\begin{array}{c}11,54 \pm 2,09^{a} \\
(n=4)\end{array}$ & $\begin{array}{c}42,67 \pm 18,89^{a, c} \\
(n=4)\end{array}$ & $\begin{array}{c}31,08 \pm 9,67^{a, c} \\
(n=5)\end{array}$ \\
\hline
\end{tabular}

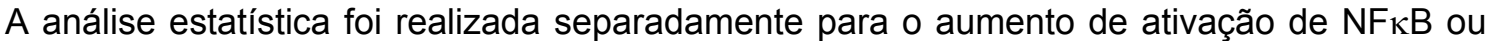
AP-1. Letras diferentes indicam diferenças significativas (ANOVA - Newman-Keuls, $p<$ 0.05). Dados expressos como Média \pm EPM.

\subsection{A estimulação dos adrenoceptores $\alpha$ e $\beta$ na ativação de NFKB e AP-1 em células secretoras da glândula de veneno da Bothrops jararaca}

A extração de veneno que promove liberação endógena de noradrenalina (KERCHOVE et al., 2004) ativa fatores de transcrição tais como NFкB e AP-1. É também sabido que a estimulação de adrenoceptores $\alpha$ e $\beta$ desencadeia o ciclo de produção de veneno (YAMANOUYE et al., 2000, KERCHOVE et al., 2004; ZABLITH, 2007). Portanto, tornou-se interessante verificar se a estimulação dos adrenoceptores estaria envolvida na ativação dos fatores de transcrição, visto que é amplamente conhecido que a estimulação dos adrenoceptores $\alpha$ e $\beta$ de mamíferos pode ativar NFKB e/ou AP-1 (BARKA; GUBITS; VAN DER NOEN, 1986; IM et al., 1998; MELDRUM et al., 1997; AKSOY et al., 2001; CHANDRASEKAR et al., 2004; TAIMOR et al., 2004; LYMPEROPOULOS et al., 2006). Para verificar o papel da inervação noradrenérgica na ativação do fator de transcrição $\mathrm{NF} \kappa \mathrm{B}$, foram utilizadas células secretoras dispersas de serpentes fêmeas no estado quiescente e estimuladas com noradrenalina $\left(10^{-4} \mathrm{M}\right)$, fenilefrina $\left(3 \times 10^{-4} \mathrm{M}\right)$, agonista do adrenoceptor $\alpha$, ou isoprenalina $\left(3 \times 10^{-4} \mathrm{M}\right)$, agonista do adrenoceptor $\beta$, durante 30 minutos. Não foram utilizadas serpentes machos devido ao tamanho da glândula de 
veneno ser menor e, conseqüentemente, a obtenção de um baixo o número de células secretoras, necessitando um número maior de animais.

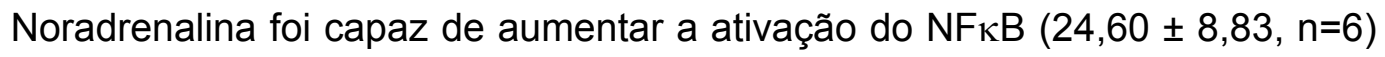
em células secretoras quiescentes da glândula de veneno da Bothrops jararaca (Figuras 8A,C). Ambos os agonistas, fenilefrina e isoprenalina, foram capazes de

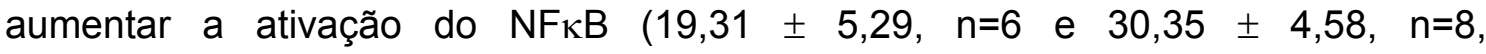
respectivamente, Figuras $8 \mathrm{~B}, \mathrm{C})$.
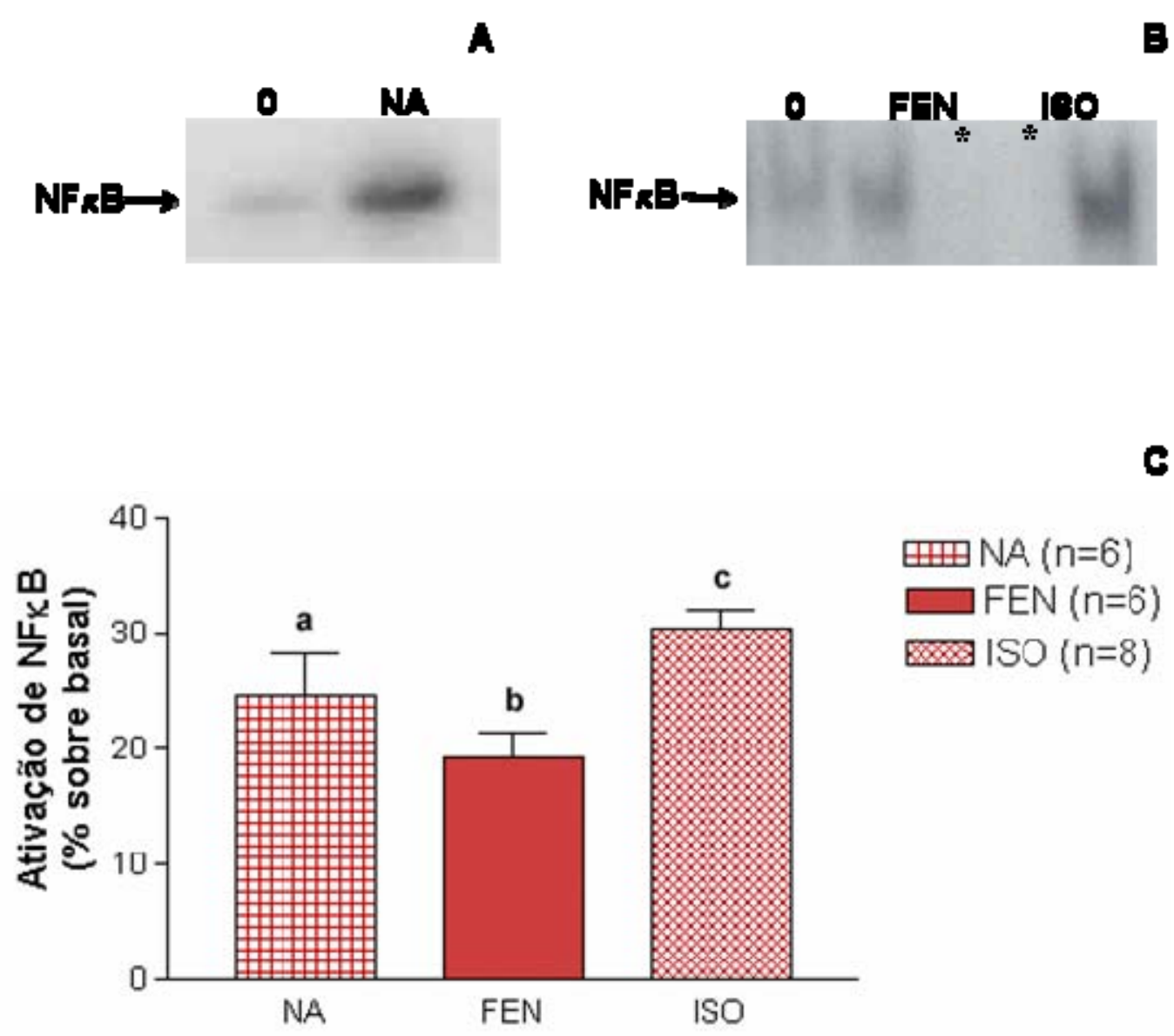

Figura 8: Estimulação dos adrenoceptores $\alpha$ e $\beta$ ativa $N F \kappa B$ em células secretoras quiescente da glândula de veneno da Bothrops jararaca. Ensaios de géis de retardo representativos de extratos nucleares de células secretoras da glândula de veneno no estado quiescente de serpentes fêmeas $(0$, basal) ou estimuladas com noradrenalina (NA) $10^{-4} \mathrm{M}(\mathrm{A})$, ou fenilefrina (FEN) $3 \times 10^{-4} \mathrm{M}$ ou isoprenalina (ISO) $3 \times 10^{-4} \mathrm{M}$ (B) por 30 minutos. * Ensaios de competição realizado usando

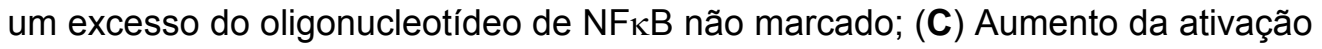
do NFкB sobre o basal mensurado por densitometria dos géis de retardo dos extratos nucleares de células secretoras dispersas incubadas com NA, FEN ou ISO. Letras diferentes indicam diferenças significativas (ANOVA - NewmanKeuls, $p<0.05)$. 
Para verificar o papel da inervação noradrenérgica na ativação do fator de transcrição AP-1, foram utilizadas células dispersas no estado quiescente $\mathrm{e}$ estimuladas com noradrenalina $\left(10^{-4} \mathrm{M}\right)$, fenilefrina $\left(3 \times 10^{-4} \mathrm{M}\right)$ ou isoprenalina $(3 \mathrm{x}$ $10^{-4} \mathrm{M}$ ) durante 30 ou 60 minutos, visto que a maior ativação de AP-1 ocorreu 60 minutos após a extração de veneno.

Noradrenalina foi capaz de aumentar a ativação do AP-1 em células secretoras quiescentes da glândula de veneno estimuladas por $30(12,01 \pm 4,21$, $n=3)$ e $60(19,19 \pm 5,92, n=4)$ minutos (Figuras 9A, B, C, e D). Nas células secretoras quiescentes estimuladas por $30 \mathrm{~min}$, isoprenalina, agonista do adrenoceptor $\beta$, foi capaz de aumentar a ativação de AP-1 $(25,49 \pm 7,73, n=3$, Figuras $9 \mathrm{~A}$ e B), enquanto que fenilefrina, agonista do adrenoceptor $\alpha$, reduziu a ativação de AP-1 em relação ao controle $(-12,67 \pm 2,94$, n=9, Figuras 9 A e B).

Nas células secretoras quiescentes estimuladas por 60 minutos, ambos os agonistas, isoprenalina e fenilefrina, foram capazes de aumentar a ativação de AP-1 $(25,52 \pm 12,30, n=5$ e $13,93 \pm 6,81, n=6)$ respectivamente (Figuras $9 \mathrm{C}$ e $D)$. 

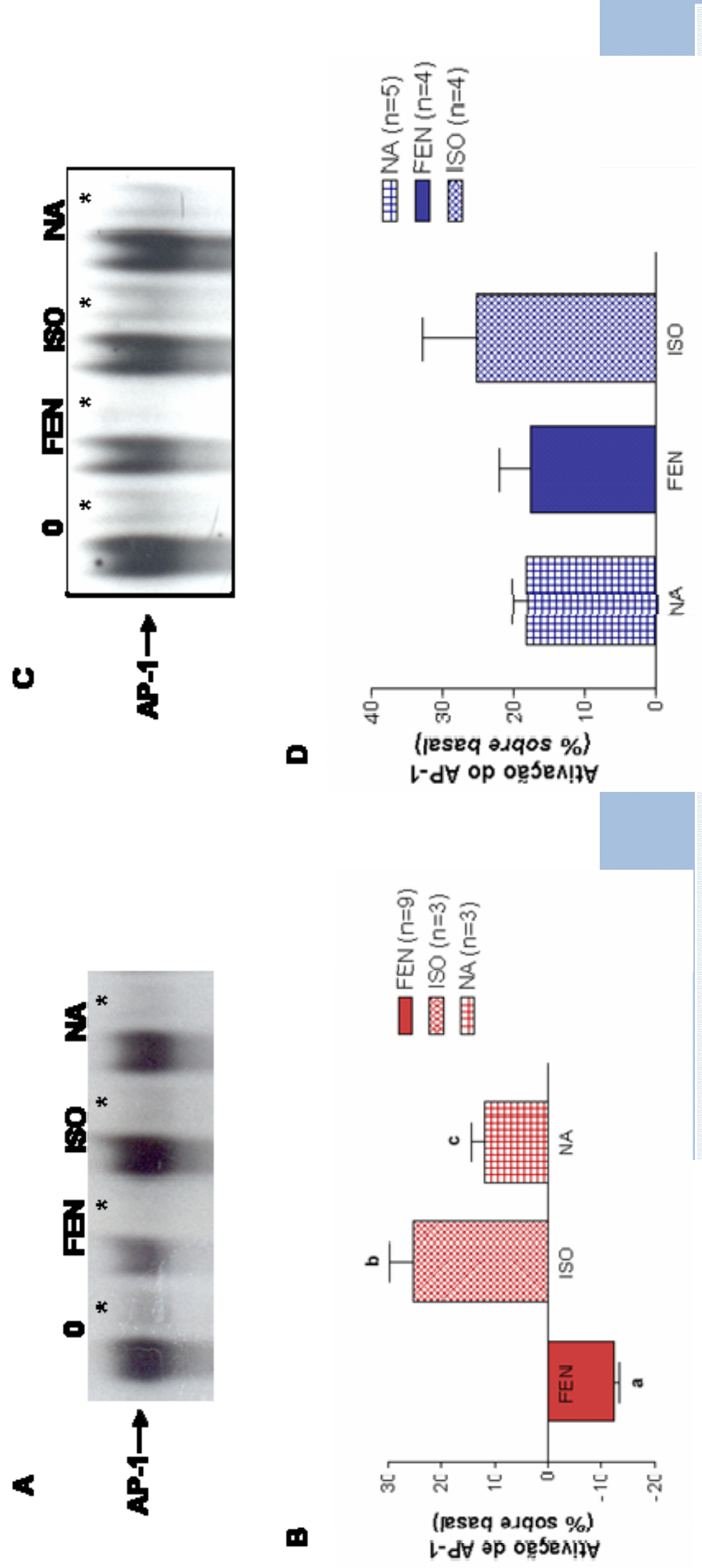

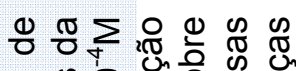

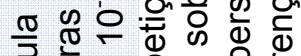

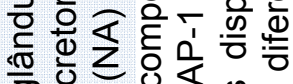
万) 중

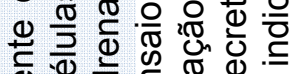
D.

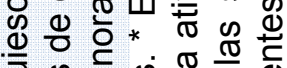
亏워

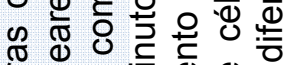
б응

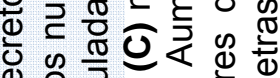
क 要

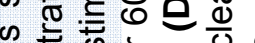
西 응 ह

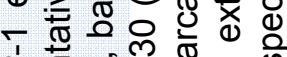
दे

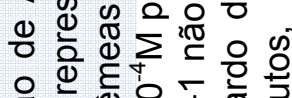

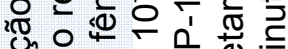
幽응

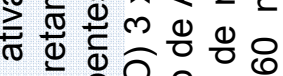
๘ 遇 象

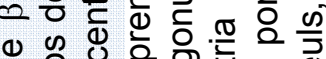

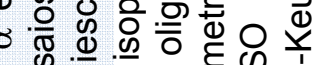
幽 ธ่ำㅇำ 政 ฮ준 ब․

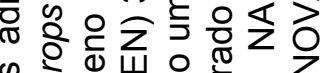

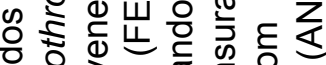
$\circ>0$ 舟 20

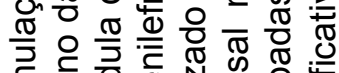

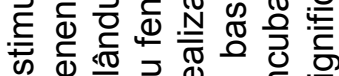

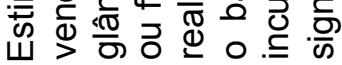
ตั 


\subsection{Participação dos adrenoceptores $\alpha$ e $\beta$ na síntese de proteínas do veneno da serpente Bothrops jararaca}

Como verificado acima, a estimulação dos adrenoceptores $\alpha$ e/ou $\beta$ modulam a ativação de fatores de transcrição tais como NFKB e AP-1, sugerindo um papel importante na regulação da síntese protéica. Para verificar se a estimulação dos adrenoceptores $\alpha$ e $\beta$ está envolvida na síntese de diferentes toxinas do veneno, as serpentes foram tratadas com reserpina com o intuito de depletar os estoques endógenos de catecolaminas (YAMANOUYE et al., 1997) e logo após a extração de veneno (ativação das células secretoras) uma dose de fenilefrina (100 mg/kg, s.c.) ou isoprenalina (100 mg/kg, s.c.), agonistas dos adrenoceptores $\alpha$ e $\beta$, respectivamente, foi administrada. O veneno coletado para ativar a glândula de veneno (controle individual) e após 15 dias foi analisado em SDS-PAGE. Como mostra a figura 10, não houve alteração do perfil protéico do veneno de serpente não tratada com reserpina (colunas 1 e 2). Como visto anteriormente, reserpina é capaz de bloquear totalmente a produção de veneno (YAMANOUYE et al., 1997). A administração de isoprenalina ou fenilefrina nas serpentes tratadas com reserpina restaurou a produção e secreção de veneno, entretanto, a composição do veneno foi semelhante às amostras do controle individual (colunas 3 e 4 e 5 e 6 , respectivamente). 


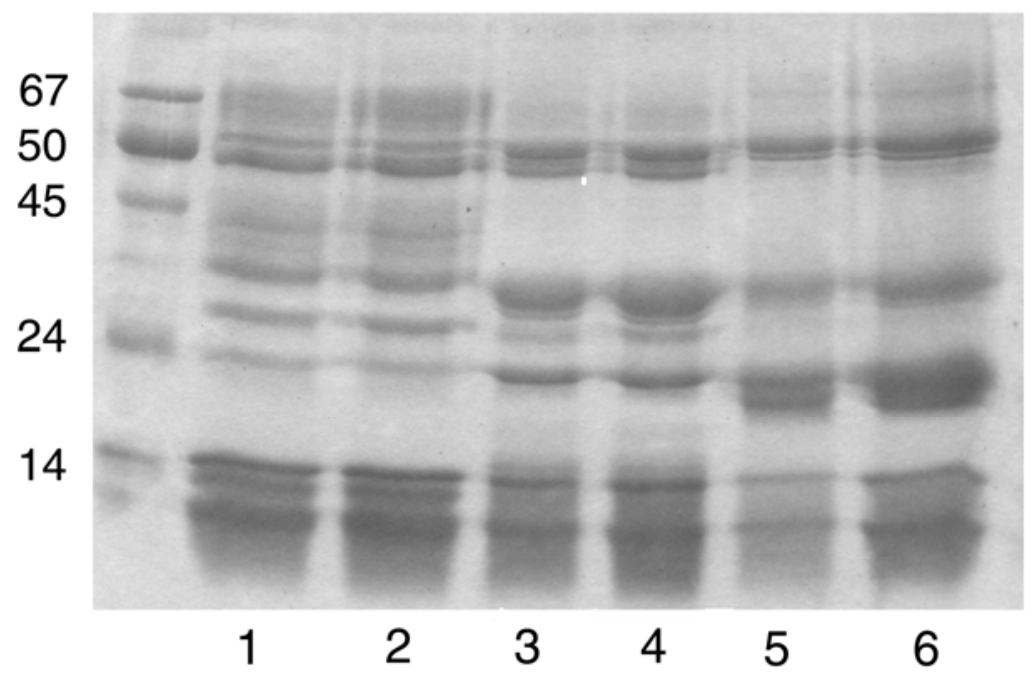

Figura 10: A estimulação dos adrenoceptores $\alpha$ e $\beta$ não participa diretamente na síntese de toxinas do veneno. $10 \mu \mathrm{g}$ de proteínas do veneno foram separadas em gel SDSPAGE (12\%). O veneno das serpentes foi extraído manualmente, duas vezes, sendo a primeira extração para a ativação da glândula de veneno e a segunda, 15 dias após, para a comparação das toxinas presentes no veneno. Colunas 1,3 e 5 correspondem aos perfis protéicos dos venenos da primeira coleta e as colunas 2, 4 e 6 aos da segunda coleta. Coluna 4 - veneno de serpente tratada com reserpina e isoprenalina (100 $\mathrm{mg} / \mathrm{kg}$, s.c.), coluna 6 - veneno de serpente tratada com reserpina e fenilefrina $(100 \mathrm{mg} / \mathrm{kg}$, s.c.). Figura representativa de 6 experimentos. 


\subsection{Análise do perfil protéico de extratos de glândula de veneno nos diferentes estágios do ciclo de produção de veneno}

Uma vez que a ativação da inervação noradrenérgica não está envolvida diretamente na síntese de toxinas do veneno, tornou-se importante verificar seu envolvimento na ativação da glândula de veneno, visto que estudos anteriores mostraram a importância da ativação dos adrenoceptores $\alpha$ e $\beta$ para o desencadeamento do ciclo de produção de veneno (YAMANOUYE et al., 2000; KERCHOVE et al., 2004; ZABLITH, 2007). O estudo iniciou pela análise dos perfis protéicos de extratos de glândulas de veneno em diferentes estágios de ativação: quiescente, 4,7 e 15 dias após a extração de veneno. Devido ao dimorfismo sexual encontrado na ativação de fatores de transcrição, foram analisados os perfis protéicos de extratos de glândulas de veneno de serpentes machos e fêmeas nos diferentes estágios do ciclo de produção de veneno.

A figura $11 \mathrm{~A}$ mostra as diferenças nos perfis protéicos dos extratos da glândula de veneno de serpentes fêmeas durante o ciclo de produção de veneno, sendo essa diferença mais significativa 4 dias após a extração de veneno, estágio do ciclo de produção de veneno onde a célula atinge o máximo em altura e é encontrada a maior concentração de RNAm para toxinas (CARNEIRO et al., 1991; DE LUCCA et al., 1974; KOCHVA, 1978; MACKESSY, 1991; ORON; BDOLAH, 1973; ROTENBERG; BAMBERGER; KOCHVA, 1971). Por exemplo, ocorreu um aumento na densidade das bandas de $81,69,47,44$ e $38 \mathrm{kDa}$ no extrato de glândula de veneno ativada por 4 dias. Nas glândulas de veneno ativadas por 7 dias houve uma redução na densidade das bandas de 28 e 19 kDa (Figura 11A).

A figura 11B mostra as diferenças nos perfis protéicos dos extratos da glândula de veneno de serpentes machos, entretanto, as maiores diferenças encontradas foram no $7^{\circ}$ dia após a extração de veneno. Por exemplo, ocorreu um aumento na densidade das bandas de 81, 69, 47 e $44 \mathrm{kDa}$, semelhante ao verificado em extrato de glândula de veneno de fêmeas, e também das bandas de 57 e 54 $\mathrm{kDa}$. Nas glândulas de veneno ativadas por 4 dias houve uma redução na densidade da banda de $28 \mathrm{kDa}$, semelhante à encontrada em extrato de glândula de veneno de fêmeas, e também das bandas de 38 e 17 kDa (Figura 11B). 

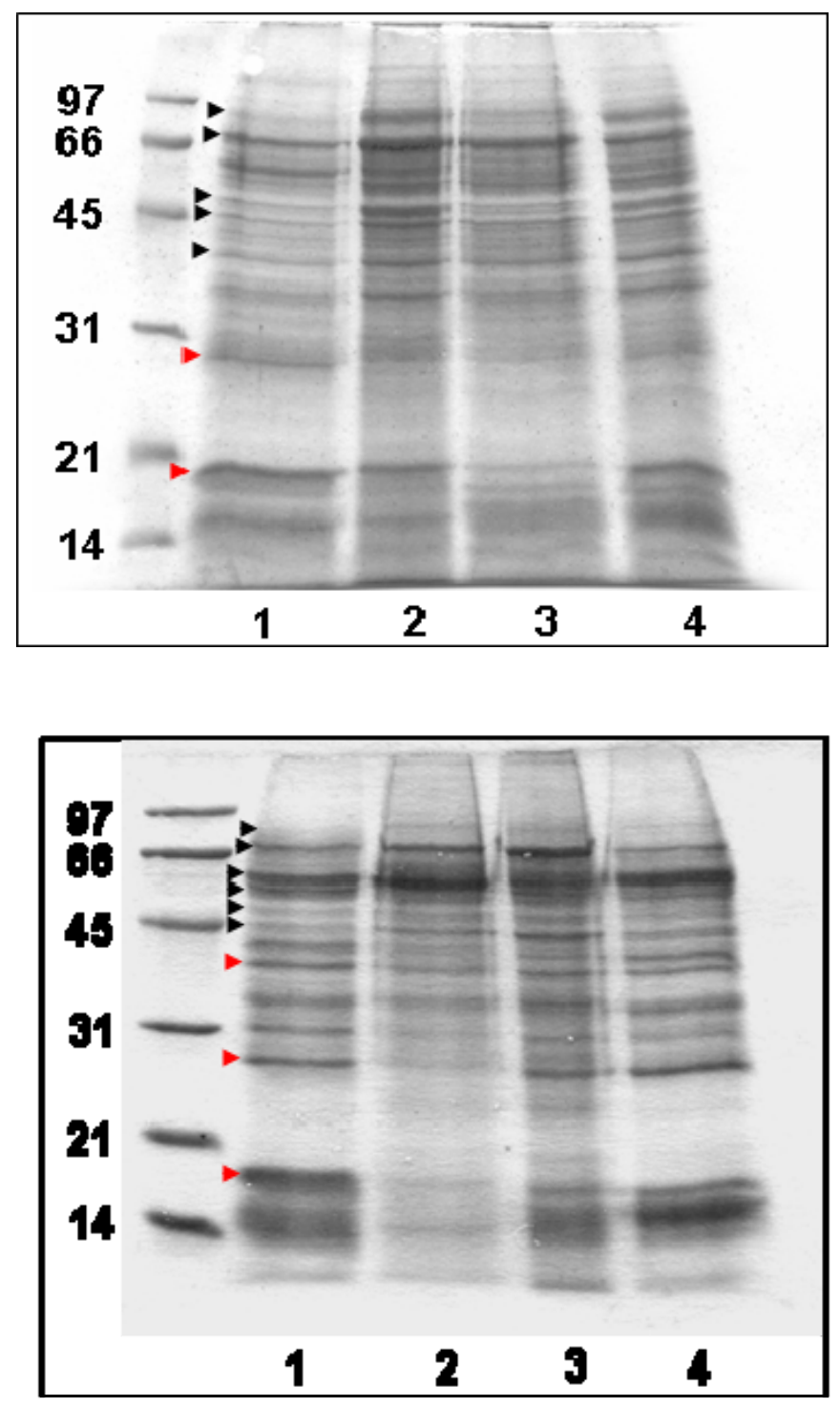

$\mathbf{B}$

Figura 11: Composição protéica das glândulas de veneno das serpentes Bothrops jararaca fêmea e macho nos diferentes estágios do ciclo de produção de veneno. (A) 15 $\mu \mathrm{g}$ de proteínas do extrato de glândula de veneno de serpentes fêmeas foram separadas em gel SDS-PAGE $(12 \%)$. Setas pretas indicam as bandas com aumento de densidade $(81,69,47,44$ e $38 \mathrm{kDa})$ no $4^{\circ}$ dia após a extração de veneno e setas vermelhas indicam as bandas com diminuição de densidade (28 e $19 \mathrm{kDa}$ ) no $7^{\circ}$ dia após extração de veneno quando comparadas com com o extrato de glândula quiescente. Figura representativa $(n=5)$. (B) $30 \mu \mathrm{g}$ de proteínas do extrato de glândula de veneno de serpentes machos foram separadas em gel SDS-PAGE (15\%). Setas pretas indicam as bandas com aumento de densidade $(81,69,57,54,47$ e $44 \mathrm{kDa})$ no $7^{\circ}$ dia após extração de veneno e setas vermelhas indicam as bandas com diminuição de densidade $(38,28$ e $17 \mathrm{kDa})$ no $4^{\circ}$ dia após extração de veneno quando comparado com extrato da glândula quiescente. Figura representativa de um experimento em duplicata. Colunas 1, 2, 3 e 4 - extratos de glândulas no estágio quiescente, 4, 7 e 15 dias após a extração de veneno, respectivamente. 


\subsection{Participação dos adrenoceptores $\alpha$ e $\beta$ na síntese de proteínas da glândula de veneno da serpente Bothrops jararaca}

Visto que a extração de veneno é capaz de ativar a glândula de veneno modificando a síntese de proteínas da glândula de veneno, foi verificada a participação da inervação noradrenérgica nesse processo.

Devido as maiores diferenças no perfil protéico terem ocorrido no quarto e sétimo dia após a extração de veneno em serpentes fêmeas e machos, respectivamente, esses tempos foram utilizados como controle.

Para verificarmos o envolvimento dos adrenoceptores $\alpha$ e $\beta$ na modulação da síntese de proteínas da glândula de veneno, serpentes fêmeas e machos foram tratadas com reserpina com o intuito de depletar os estoques de noradrenalina (YAMANOUYE et al., 1997). Algumas serpentes tratadas com reserpina receberam uma dose de fenilefrina (100 mg/kg, s.c.) e de isoprenalina (100 mg/kg, s.c.) logo após a extração de veneno, tratamento necessário para o desencadeamento do ciclo de produção de veneno (KERCHOVE et al., 2004; KERCHOVE, 2005; ZABLITH, 2007; NUNEZ-BUGOS et al., 1993). As glândulas de serpentes fêmeas foram coletadas 4 dias e dos machos 7 dias após o tratamento.

Reserpina causou alterações no perfil eletroforético dos extratos de glândulas de veneno de serpentes fêmeas quando comparadas com o controle (Figura 12A). Esse perfil é muito semelhante ao extrato de glândula quiescente (Figura 11A). Administração de fenilefrina e isoprenalina reverteram o efeito da reserpina (Figura 12A). O tratamento com reserpina reduziu a densidade das bandas de 81, 69, 47, 44 e $38 \mathrm{kDa}$ (Figura 12A) e a administração de fenilefrina e isoprenalina reverteram esse efeito. Foi verificado também que a banda de $41 \mathrm{kDa}$ teve sua densidade reduzida após tratamento com reserpina, e após a administração dos agonistas sua densidade aumentada (Figura 12A).

Nas glândulas de serpentes machos, reserpina também causou alterações no perfil eletroforético quando comparadas com o controle (Figura 12B), sendo esse perfil semelhante ao da glândula quiescente (Figura 11B). Diferente do que ocorreu nas glândulas de serpentes fêmeas, a administração de fenilefrina e isoprenalina não reverteu completamente o efeito de reserpina, sendo que somente as bandas de 57 e 54 kDa tiveram sua densidade aumenta (Figura 12B). 

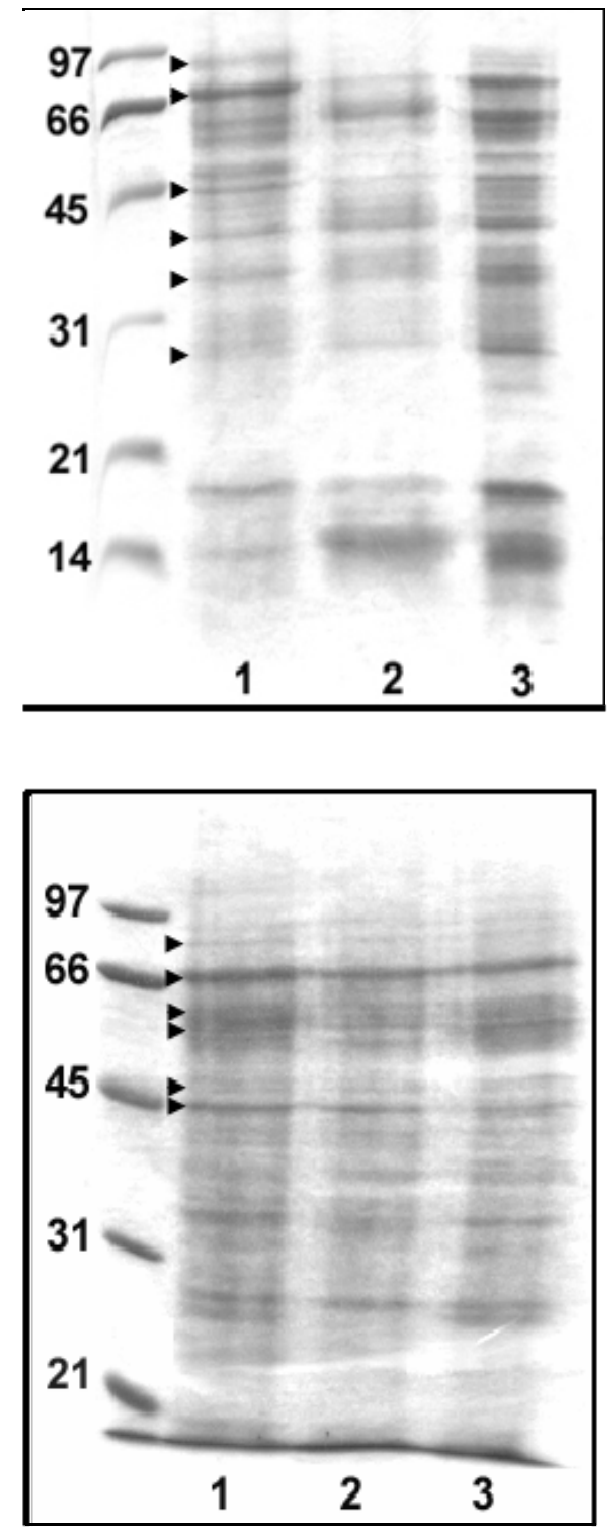

B

Figura 12: Efeito da reserpina e da estimulação dos adrenoceptores $\alpha$ e $\beta$ na composição protéica da glândula de veneno. (A) Extratos de glândulas de veneno de serpentes fêmeas 4 dias após a extração de veneno. Setas indicam as bandas com redução da densidade $(81,69,47,44,41$ e $38 \mathrm{kDa})$ na glândula de veneno de serpentes tratadas com reserpina quando comparado com glândulas de veneno ativadas (4 dias após extração de veneno). Figura representativa de dois experimentos. (B) Extratos de glândulas de veneno de serpentes machos 7 dias após a extração de veneno. Setas indicam as bandas com redução da densidade $(81,69,57,54,48$ e $44 \mathrm{kDa})$ na glândula de veneno de serpentes tratadas com reserpina quando comparado com glândulas de veneno ativadas (7 dias após extração de veneno). Figura representativa de um experimento em duplicata. Colunas 1, 2 e 3 - extratos de glândulas de veneno de serpentes controle, tratada com reserpina ou tratada com reserpina, fenilefrina e isoprenalina, respectivamente. 
5 Discussãa 
A inervação noradrenérgica tem um papel importante no desencadeamento do ciclo de produção de veneno em serpentes Bothrops jararaca. Tanto os adrenoceptores $\alpha$ como os $\beta$ estão envolvidos neste processo, visto que seus respectivos agonistas, fenilefrina e isoprenalina foram capazes de reverter o bloqueio da produção e secreção de veneno causado pela reserpina (YAMANOUYE et al., 1997; KERCHOVE et al., 2004; ZABLITH, 2007).

Nesta dissertação, foi demonstrada pela primeira vez a presença dos fatores de transcrição NFKB e AP-1 em glândulas de veneno. Foi mostrado ainda que a noradrenalina liberada após a extração de veneno promove um aumento na ativação dos fatores de transcrição NFkB e AP-1. A estimulação de ambos os adrenoceptores $\alpha$ e $\beta$ estão envolvidos nessa resposta. Além disso, a noradrenalina, atuando em adrenoceptores $\alpha$ e $\beta$, regula a síntese de proteínas da glândula de veneno que provavelmente participam da ativação da glândula de veneno para subseqüente produção de veneno.

Trabalhos anteriores do laboratório mostram que a noradrenalina, liberada após a extração do veneno, desencadeia o ciclo de produção de veneno estimulando os adrenoceptores $\alpha$ e $\beta$ presentes na glândula de veneno (YAMANOUYE et al., 1997; KERCHOVE et al., 2004; ZABLITH, 2007). Estes receptores estão acoplados a diferentes proteínas $G$ e uma vez estimulados desencadeiam diferentes vias de sinalização intracelular. Em células secretoras quiescentes da glândula de veneno da serpente Bothrops jararaca, a estimulação dos adrenoceptores $\beta$ aumenta a produção de $A M P c$ e a concentração de cálcio citosólico ativando canais de cálcio operados por voltagem e operados por receptores e mobilizando cálcio de estoques intracelulares sensíveis a tapsigargina (YAMANOUYE et al., 2000; ZABLITH, 2007), enquanto que a estimulação dos adrenoceptores $\alpha$ aumenta o fosfato de inositol total, mobiliza o cálcio de estoques intracelulares sensiveis a tapsigargina e ativa PKC e ERK (KERCHOVE, 2005). Os segundos mensageiros acima citados podem interagir com outras proteínas chaves levando a ativação de fatores de transcrição e contribuindo para regulação da expressão gênica (MARINISSEN; GUTKIND, 2001). A ativação de fatores de transcrição é complexa e pode envolver múltiplas vias de sinalização intracelular, incluindo quinases como a PKC, PKA, MAPK e PI3K estimuladas por receptores de membrana (KARIN, 1995; McBRIDE; NEMER, 1998; LYMPEROPOULOS et al., 
2006). É interessante notar que em glândulas de veneno, a estimulação do adrenoceptor $\beta$ ativa tanto NFאB quanto AP-1, no entanto, o adrenoceptor $\alpha$ ativa o $\mathrm{NF} \kappa \mathrm{B}$, mas a ativação do AP-1 ocorre apenas tardiamente. Apesar de ambos os adrenoceptores $\alpha$ e $\beta$ estarem envolvidos na ativação de fatores de transcrição, o efeito de noradrenalina não é a somatória dos efeitos de fenilefrina e isoprenalina, levando se a supor que ocorra uma interação entre as sinalizações desencadeadas pela estimulação dos adrenoceptores $\alpha$ e $\beta$ e, portanto, o efeito de noradrenalina é uma resultante dessa interação. Vale ressaltar que a estimulação dos

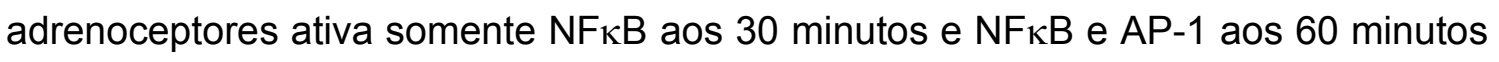
sugerindo que diferentes genes são transcritos no decorrer do ciclo de produção de veneno.

Os dados obtidos neste estudo vão de encontro com os da literatura onde mostram que tanto a ativação de adrenoceptores $\alpha$ como de $\beta$ induz a expressão de c-Fos e c-Jun em uma variedade de células como em cardiomiócitos (IWAKI et al., 1990; TAIMOR et al., 2004), neuroblastomas (SHILLING et al., 1991), células do músculo liso vascular (OKAZAKI et al., 1994), adipócitos (THONBERG et al., 1994) e hepatócitos (GARCIA-SÁINZ; ALCÁNTARA-HERNÁNDEZ, 1996; IM et al., 1998). Todos os subtipos de adrenoceptores $\alpha_{1}$ são capazes de induzir a expressão de cFos e c-Jun, e a PKC parece tem um papel importante mediando estes efeitos. Entretanto, a eficácia em induzir os genes de ativação imediata varia de acordo com o subtipo do adrenoceptor $\alpha_{1}$, (GARCÍA-SÁINZ; ALCÁNTARA-HERNÁDEZ; VÁZQUEZ-PRADO, 1998). Além disso, a estimulação de ambos os adrenoceptores $\alpha$ e $\beta$ também ativa NFKB (MELDRUM et al., 1997; CHANDRASEKAR et al., 2004; LYMPEROPOULOS et al., 2006).

A utilização de reserpina para depletar a noradrenalina endógena nos possibilitou a descoberta da importância da inervação noradrenérgica para a ativação da glândula de veneno. O tratamento das serpentes com reserpina manteve a glândula de veneno no estado quiescente, mesmo após a extração de veneno. Reserpina tem sido utilizada como ferramenta farmacológica para desvendar o papel da inervação simpática em glândulas salivares de ratos, mas o tratamento crônico com esta droga promove alterações morfológicas e funcionais irreversíveis em glândulas salivares exócrinas, similar as alterações encontradas em 
pacientes com fibrose cística (MARTINEZ et al., 1975a; MARTINEZ et al., 1975b; WATSON et al., 1984; JOHNSON, 1988). Em serpentes, o tratamento crônico com reserpina não é lesivo para a glândula de veneno, uma vez que a estimulação dos adrenoceptores reverte o seu efeito (YAMANOUYE et al., 1997). A reversão do efeito da reserpina pode ser devido à capacidade da glândula de veneno manter-se no estado quiescente, ao contrário das glândulas salivares que estão constantemente no estado ativado.

Este estudo mostra que noradrenalina promove a ativação de fatores de transcrição que levam à regulação da síntese de proteínas da glândula de veneno. Este resultado sugere que a produção de uma mistura complexa de proteínas é determinada por um programa fixo de alterações bioquímicas nas células produtoras de veneno que levam à sua ativação. A estimulação da inervação noradrenérgica parece desencadear o início desse programa, uma vez que não está envolvida na síntese de proteínas do veneno. Esses dados corroboram com os obtidos por Nunes-Burgos et al. (1993), onde a adminstração crônica de isoproterenol em serpentes altera a composição de proteínas da glândula de veneno no estado quiescente. Portanto, o papel da inervação noradrenérgica em regular a síntese de proteínas da glândula de veneno essenciais para sua ativação verificada neste trabalho, esclarece a importância dessa inervação para o desencadeamento do ciclo de produção de veneno (YAMANOUYE, et al., 2000; KERCHOVE et al., 2004; ZABLITH, 2007).

É interessante notar que a administração de fenilefrina e isoprenalina após tratamento com reserpina reverteu os efeitos da reserpina em glândula de veneno de serpentes fêmeas 4 dias após a extração de veneno (ver Figura12A, bandas de 81, 69, 47 e $38 \mathrm{kDa}$ ), período onde foram encontradas as maiores diferenças. Em glândulas de serpentes machos as maiores diferenças encontradas foram 7 dias após a extração de veneno, e neste período, fenilefrina e isoprenalina reverteu parcialmente o efeito de reserpina, onde somente as bandas de 57 e 54 kDa tiveram sua densidade aumentada (Figura 12B). Esses resultados nos levam a supor que outros fatores ou mesmo neurotransmissores estariam atuando mais tardiamente, influenciando a resposta dos agonistas de adrenoceptores, como por exemplo a acetilcolina, cujo papel em glândulas salivares é muito conhecido. 
É sabido que a inervação simpática tem um papel importante na regulação da síntese e secreção de proteínas salivares (BARKA et al., 1986; WOON; JEYASEELAN; THIYAGARAJAH, 1993; ANN; LIN, 1997; ANN; LIN, 1998; LI et al., 2006; PROCTOR; CARPENTER, 2007).

A importância da estimulação dos adrenoceptores $\alpha$ em glândulas salivares está principalmente na secreção de fluídos, eletrólitos, amilase e mucinas (QUISSEL; BARZEN; DEISHER, 1993; KLEIN, 2002). A administração de fenilefrina, em coelhos transplantados com glândulas submandibulares, promove um aumento da expressão do RNAm dos subtipos do adrencoceptor $\alpha_{1 A}, \alpha_{1 B}$ e $\alpha_{1 D}$ e melhora a função secretora, promovendo a regeneração das glândulas transplantadas (XIANG et al., 2006). Outros trabalhos na literatura também mostraram que o RNAm dos subtipos de adrenoceptores $\alpha_{1 \mathrm{~A}} \mathrm{e} \alpha_{1 \mathrm{~B}}$ são expressos em glândulas submandibulares de ratos (NISHIURA; GAO; ABE, 2001; BOCKMAN et al., 2004) e humanos (HUANG et al., 2006) e a síntese e estimulação desses receptores podem contribuir para regulação da secreção de saliva. $O$ adrenoceptor $\alpha_{1}$ presente na glândula de veneno é do subtipo $\alpha_{1 \mathrm{D}}$ (KERCHOVE, 2005) e a estimulação desse receptor regula a síntese de proteínas da glândula, mas é pouco provável que este receptor esteja promovendo a síntese de adrenoceptores $\alpha$, visto que após sua estimulação, estes sofrem dessensibilização de longa duração (KERCHOVE et al., 2004).

A importância da estimulação dos adrenoceptores $\beta$ em glândulas salivares não está somente em promover a secreção de saliva, mas também em promover a síntese de proteínas da saliva (BAUM; WELLNER, 1999). O tratamento crônico com isoprenalina em mamíferos induz a hipertrofia e hiperplasia das células acinares das glândulas submandibular e da parótida e também promove aumento da síntese de DNA e RNA levando a alterações protéicas da glândula (BARKA, 1965; BROWNGRANT, 1961; SCHNEYER, 1962; SELYE; VEILLEUX; CANTIN, 1961; VULGMAN; HAND, 1995; WOON; JEYASEELAN; THIYAGARAJAH, 1993). Através da tecnologia de "microarray", Ten Hagen et al. (2002) mostraram alterações na expressão gênica da glândula parótida de murinos em resposta ao tratamento crônico com isoprenalina. Proteínas com diferentes funções celulares foram reguladas pela estimulação do adrenoceptor $\beta$ e podem estar relacionadas à hiperplasia ou hipertrofia verificada. Não há estudos na literatura relacionando a 
estimulação dos adrenoceptores $\alpha$ nas glândulas salivares e síntese de proteínas como verificado para os adrenoceptores $\beta$. Em glândula de veneno não foi verificada hiperplasia ou hipertrofia após tratamento crônico com isoprenalina (NUNESBURGOS et al., 1993). Essa diferença pode ser devido ao fato da glândula salivar estar em constante estado de ativação e uma hiperestimulação levaria a hiperplasia ou hipertrofia dessas glândulas. A glândula de veneno por possuir estados de quiescência e ativado distintos possibilitou a descoberta da importância tanto dos adrenoceptores $\beta$ como dos $\alpha$ para sua ativação. A inervação simpática parece regular a produção dos componentes da maquinaria que irão ativar a glândula de veneno e levar à produção de veneno, ao invés de regular a síntese e secreção de toxinas do veneno.

Outro fato importante verificado nesta dissertação foi a presença do dimorfismo sexual na ativação de ambos os fatores de transcrição, NFkB e AP-1, na glândula de veneno. A ativação de $\mathrm{NF \kappa B}$, foi mais rápida nas serpentes fêmeas (30 minutos) do que nos machos (60 minutos) e a ativação máxima de AP-1 foi maior nas fêmeas do que nos machos. Em sincronia com a ativação dos fatores de transcrição na glândula de veneno, as modificações dos perfis protéico da glândula de veneno após extração de veneno ocorrem mais cedo nas fêmeas (4 dias após a extração de veneno) do que nos machos (7 dias após a extração e veneno).

O termo dimorfismo sexual refere-se a diversas diferenças que podem ser morfológicas, bioquímicas ou fisiológicas que podem se manifestar como diferenças no tamanho, na aparência morfológica, na atividade metabólica, nas respostas a hormônios, na sensibilidade a drogas, entre outros. O primeiro relato de dimorfismo sexual em glândulas salivares (LACASSAGNE, 1940) foi relacionado às diferenças morfológicas nas glândulas submandibulares de camundongos. No entanto, diferenças relacionadas ao sexo, na estrutura e função de glândulas submandibular, sublingual e parótida de várias espécies animais têm sido descritas (para revisão ver PINKSTAFF, 1998). As principais diferenças morfológicas encontradas estão no sistema de ductos e nos diferentes tipos celulares presentes nos ductos das glândulas salivares de camundongos e ratos machos e fêmeas (CHAl et al., 1993; DA CUNHA LIMA et al., 2004; HIPKAEO; WAKAYAMA; YAMAMOTO, 2004). Uma das diferenças observadas foi a presença de uma maior população de células do ducto estriado nos machos e de células do ducto granular estriado nas fêmeas 
(CHAl et al., 1993; HIPKAEO; WAKAYAMA; YAMAMOTO, 2004). O dimorfismo sexual tem sido atribuído, em parte, por diferenças específicas na expressão gênica de cada glândula (TREISTER et al., 2005). Sabe-se que as células dos ductos da glândula salivar de mamíferos apresentam, no decorrer de seu desenvolvimento, mudanças morfológicas dependentes de andrógeno, levando a um acentuado dimorfismo sexual (CARAMIA 1966; CHRETIEN, 1977). A expressão e localização de fatores de transcrição tais como AP-1 apresenta um dimorfismo sexual em ducto da glândula submandibular de camundongo, onde a imunoreatividade de JunD é maior nas fêmeas do que nos machos (HIPKAEO; WAKAYAMA; YAMAMOTO, 2004). CREB, cuja função está na diferenciação das células acinares da glândula submandibular via adrenoceptor $\beta$, possui também um papel importante no crescimento e diferenciação das células regulada por andrógeno no sistema de ductos (AMANO; ISEKI, 1998).

As glândulas de veneno são glândulas exócrinas relacionadas com as glândulas salivares e apresenta um dimorfismo sexual na ativação de fatores de transcrição e no perfil protéico das glândulas de veneno ativadas por extração de veneno. Esses dados estão de acordo com os obtidos recentemente por Menezes et al., 2006, onde mostraram através da análise proteômica dos venenos individuais de serpentes Bothrops jararaca de uma mesma ninhada, a presença de dimorfismo sexual. Foram encontradas diferenças no conteúdo protéico entre o veneno das serpentes fêmeas e dos machos e também diferenças nas atividades das toxinas. $A$ atividade fibrinogenolítica é maior nas fêmeas do que nos machos e a atividade amidolítica é maior nos machos do que nas fêmeas, e estas diferenças parecem ser geneticamente herdadas e impostas por forças evolucionárias (MENEZES et al., 2006).

Nesta dissertação mostramos que a estimulação de ambos os adrenoceptores $\alpha$ e $\beta$ ativam fatores de transcrição e a resultante dessa ativação leva à regulação da síntese de uma gama de proteínas da glândula de veneno que estão envolvidas na sua ativação, para posterior produção e secreção de veneno em glândulas de veneno da serpente Bothrops jararaca. As glândulas de veneno, ao contrário das glândulas salivares, podem assumir estados quiescente e ativado distintos sendo, portanto, um modelo ideal para o estudo dos mecanismos 
fisiológicos envolvidos na produção e secreção de proteínas em glândula exócrina, visto que esse mecanismo pode ser estudado passo a passo.

Este estudo é de fundamental importância para o entendimento da dinâmica da glândula de veneno, visto que a compreensão dos mecanismos envolvidos na produção e secreção de veneno será de grande valia para o estabelecimento de uma linhagem de células secretoras funcionais que produza veneno in vitro, com atividade biológica semelhante ao veneno obtido da serpente. 
6 Canclusãa 
Em resumo os resultados obtidos mostraram que:

- Extração de veneno, o qual promove a liberação endógena de noradrenalina, ativa os fatores de transcrição NFאB e AP-1;

- A estimulação do adrenoceptor $\alpha$, é capaz de ativar os fatores de transcrição NFkB e AP-1, entretanto, a ativação de AP-1 ocorre mais tardiamente;

- Estimulação do adrenoceptor $\beta$ é capaz de ativar ambos fatores de transcrição NFKB e AP-1;

- A ativação dos fatores de transcrição por noradrenalina é uma resultante da estimulação dos adrenoceptores $\alpha$ e $\beta$;

- A estimulação dos adrenoceptores $\alpha$ e $\beta$ alteram a síntese de proteínas da glândula de veneno e não a síntese de proteínas do veneno;

- Ocorre dimorfismo sexual na ativação do NFkB e AP-1 e no perfil protéico da glândula de veneno nos diferentes estágios do ciclo de produção de veneno.

Em conclusão os resultados sugerem que a inervação simpática participa do desencadeamento do ciclo de produção de veneno estimulando os adrenoceptores $\alpha$ e $\beta$ que regulam a ativação de fatores de transcrição, promovendo a síntese de proteínas da glândula que possivelmente são essenciais para sua ativação e não diretamente na síntese de veneno. 


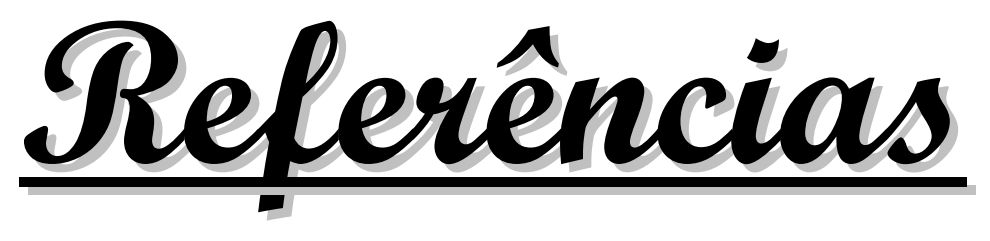

Bibliagráficas 
AKSOY, M.O.; BIN, W.; YANG, Y.; YUN-YOU, D.; KELSEN, S.G. Nuclear factor-кB augments $\beta 2$-adrenergic receptor expression in human airway epithelial cells. Am. J. Physiol. Lung Cell Mol. Physiol., v. 281, p. L1271-L1278, 2001.

AMANO, O.; ISEKI, S. Occurrence and nuclear localization of cAMP response element-binding protein in the post-natal development of the rat submandibular gland. Histochem. J., v. 30, p. 591-601, 1998.

AMSTERDAM, A.; OHAD, I.; SHRAMM, M.M. Dynamic changes in the ultrastructure of acinar of the rat parotid gland during the secretory cycle. J. Cell Biol., v. 41, p. 753-773, 1969.

ANGEL, P. Multigene family of transcription factor AP-1. In: BRADSHAW, R.A.; DENNIS, E.A. Handbook Cell Signaling. San Diego, California, Academic Press, 2004. p. 99-105.

ANN, D.K.; LIN, H.H. Regulation of salivary-gland-specific gene expression. Crit. Rev. Oral Biol. Med., v. 8, n. 3, p. 244-252, 1997.

ANN, D.K.; LIN. H.H. Transcriptional regulation of salivary proline-rich protein gene expression. Ann. N. Y. Acad. Sci., v. 842, p. 108-114, 1998.

ARAÚJO, F.A.A.; SANTALÚCIA, M.; CABRAL, R.F. Epidemiologia dos acidentes por animais peçonhentos. In: CARDOSO, J.L.C.; FRANÇA, F.O.S.; WEN, F.H.; MÁLAQUE, C.M.S.; HADDAD, V.Jr. Animais Peçonhentos no Brasil: Biologia, Clínica e Terapêutica dos acidentes. São Paulo: Sarvier, 2003. p. 6-12.

BAEUERLE, P.A.; BALTIMORE, D. Activation of DNA-binding activity in an apparently cytoplasmic precursor of the NF-KB transcription factor. Cell, v. 53, p. 211-217, 1988.

BARKA, T. Stimulation of DNA synthesis by isoproterenol in the salivary gland. Exp. Cell Res., v.39, p. 355-364, 1965.

BARKA, T.; YAGIL, C.; NOEN, H.V.D.; NAITO, Y. Induction of the synthesis of a specific protein in rat submandibular gland by isoproterenol. Lab. Investig., v. 54, n. 2, p. 165-171, 1986. 
BARKA, T.; GUBITS, R.M.; VAN DER NOEN, H. M. $\beta$-Adrenergic stimulation of c-fos gene expression in the mouse submandibular Gland. Mol. Cell Biol., v. 6, n. 8, p. 2984-2989, 1986.

BARKA, T. $\beta$-Adrenergic effects on salivary glands: growth and gene regulation. Acta Histochem. Cytochem., v. 23, p. 245-255, 1990.

BAUM, B.J. Principles of saliva secretion. Ann. N.Y. Acad. Sci., v. 694, p. 17-23, 1993.

BAUM, B.J.; WELLNER, R.B. Neural mechanisms of salivary gland and secretion: receptors in salivary glands. In: GARRET, J.R.; EKSTRÖM, J.; ANDERSON, L.C. Front Oral Biology. (Ed.). Basel: Karger, 1999. p. 44-58.

BELLUOMINI, H.E. Extraction and quantities of venom obtained from some Brazilian snakes. In: BUCHERL, W.; BUCKLEY, V.; DEULOFEU, V. Venomous Animals and their Venoms. New York: Academic Press, v. 1, 1967. p. 97-117.

BEN-SHAUL, Y.; LIFSHITZ, S.H.; KOCHVA, E. Ultrastructural aspects of secretion in the venom glands of Vipera Palaestinae. In: DE VRIES, A. Toxins of Animal and Plant Origen. London: Gordon and Breach, 1971. p. 87-107.

BERAUD, C.; HENZEL, W.J.; BAEUERLE, P.A.; Involvement of regulatory and catalytic subunits of phosphoinositide 3-kinase in NF-kB activation. Proc. Natl. Acad. Sci. USA, v. 96, p. 429-434, 1999.

BDOLAH, A. The venom glands of snakes and venom secretion. In: LEE, C.Y. Snake Venom. Berlin: Springer Verlag, 1979. p. 41-57, (Handbook Experimetal Pharmacology, 52).

BOCKMAN, C.S.; BRUCHAS, M.R.; ZENG, W.; O'CONNELL, K.A.; ABEL, P.W.; SCOFIELD, M.A.; DOWD, F.J. Submandibular gland acinar cells express multiple $\alpha_{1-}$ adrenoceptor subtypes. J. Pharmacol. Exp. Ther., v. 311, n. 1, p. 364-372, 2004.

BRADFORD, M. A rapid and sensitive method for the quantification of micrograms quantities of protein utilizing the principle of protein-dye binding. Anal. Biochem., v. 72, p. 248-54,1976.

BRENO, M.C.; YAMANOUYE, N.; PREZOTO, B.C.; LAZARI, M.F.M.; TOFFOLETTO, O.; PICARELLI, Z.P. Maintenance of the snake Bothrops jararaca (Wied, 1824) in captivity. The snake, v. 22, p. 126-130, 1990. 
BROWN-GRANT, K. Enlargement of salivary gland in mice treated with isopropylnoradrenaline. Nature, v. 191, p. 1076-1078, 1961.

CARAMIA, F. Ultrastructure of the mouse submaxillary gland. II. Effect of castration in the male. J. Ultrastruct. Res., v. 16, p. 505-523, 1966.

CARNEIRO, S.M.; PINTO, V.R.; JARED, C.; LULA, L.A.B.M.; FARIA, F.P.; SESSO, A. Morphometric studies on venom secretory cells from Bothrops jararacussu (jararacuçu) before and after venom extraction. Toxicon, v. 29, n. 6, p. 569-580, 1991.

CHIPPAUX, J.P.; WILLIAMS, V.; WHITE, J. Snake venom variability: methods of study, results and interpretation. Toxicon, v. 29, n. 11, p. 1279-1303, 1991.

CHAI, Y.; KLAUSER, D.K.; DENNY, P.A.; DENNY, P.C. Proliferative and structural differences between male and female mouse submandibular glands. Anat. Rec., v. 311, p. 235-303, 1993.

CHRETIEN, M. Action of testosterone on the differentiation and secretory activity of a target organ: the submaxillary gland of the mouse. Int. Rev. Cytol., v. 50, p. 333-396, 1977.

CHANDRASEKAR, B.; MARELLI-BERG, F.M.; TONE, M.; BYSANI, S.; PRABHU, S.; MURRAY, D.R. $\beta$-Adrenergic stimulatio induces interleukin-18 expression via $\beta_{2}-A R$, PI3K, Akt, IKK, and NF-kB. Biochem. Biophys. Res. Commun., v. 319, p. 304-311, 2004.

CHEN, L.F.; GREENE, W.C. Shapping the nuclear action of NF-кB. Mol. Cell Biol., v. 5 , p. 392-401, 2004.

DA CUNHA LIMA, M.; SOTTOVIA-FILHO, D.; CESTARI, T.M.; TAGA, R. Morphometric characterization of sexual differences in the rat sublingual gland. Braz. Oral Res., v. 18, n. 1, p. 53-58, 2004.

DE LUCCA, F.L.; HADDAD, A.; KOCHVA, E.; ROTHSCHILD, A.M.; VALERI, V. Protein synthesis and morphological changes in the secretory epithelium of the venom gland of Crotalus durissus terrificus at different times after manual extraction of venom. Toxicon, v. 12, n. 4, p. 361-369, 1974. 
FERREIRA, S.H. A Bradykinin-potentiating factor (BPF) present in the venom of Bothrops jararaca. Br. J. Pharmacol. Chemother., v. 24, p. 163-169, 1965.

FREDRISSON, R.; LAGERSTRÖM, M.C.; LUNDIN, L.G.; SCHIÖTH, H.B. The Gprotein-coupled receptors in the human genome form five main families. Phylogenetic analysis, paralogon groups, and fingerprints. Mol. Pharmacol., v. 63, n. 6, 2003.

FUNDAÇÃO NACIONAL DE SAÚDE. Manual de diagnóstico e tratamento por animais peçonhentos. 2. ed. Brasília, DF: FUNASA, 2001. $112 \mathrm{f}$.

GARCIA-SÁINZ, J.A.; ALCÁNTARA-HERNÁNDEZ, R. $\alpha_{1}$ - and $\beta$-Adrenoceptor activation increase c-fos expression in isolated guinea pig hepatocytes. Pharmacol. Commun., v. 7, p. 107-113, 1996.

GARCIA-SÁINZ, J.A.; ALCÁNTARA-HERNÁNDEZ, R.; VÁZQUEZ-PRADO, J. $\alpha_{1}$ Adrenoceptor subtype activation increases proto-oncogene mRNA levels. Role of protein kinase C. Eur. J. Pharmacol., v. 342, p. 311-317, 1998.

GARCIA-SÁINZ, J.A.; VÁZQUEZ-PRADO, J.; MEDINA, L.D.C. $\alpha_{1}$-Adrenoceptors: function and phosphorylation. Eur. J. Pharmacol., v. 389, p. 1-12, 2000.

GETHER, U. Uncovering Molecular Mechanisms Involved in Activation of G ProteinCoupled Receptors. Endocr. Rev., v. 21, p. 90-113, 2000. Review.

GOMES, N.; PUORTO, G. Atlas anatômico de Bothrops jararaca Wied, 1824 (Serpentes: Viperidae). Mem. Inst. Butantan, v. 55, p. 69-100, 1993.

GONÇALVES, L.C.R.; YAMANOUYE, N.; NUNEZ-BURGOS, G.B.; FURTADO, M.F.; BRITTO, L.R.G.; NICOLAU, J. Detection of calcium-binding proteins in venom and Duvernoy's glands of South America snakes and their secretions. Comp. Biochem. Physiol. C., v. 118, n. 2, p. 207-211, 1997.

GOPALAKRISHNAKONE, P.; KOCHVA, E. Unusual aspects of the venom apparatus of the blue coral snake, Maticora bivirgata. Arch. Histol. Cytol., v.53, n.2, p. 199210, 1990.

GOPALAKRISHNAKONE, P.; KOCHVA, E. Histological features of the venom apparatus of sea snake Lapemis curtus. Snake, v. 25, p. 27-37, 1993. 
GROSSMANN, M.; O'REILLY, L.A.; GUGASYAN, R.; STRASSER, A.; ADAMS, J.M.; GERONDAKIS, S. The anti-apoptotic of Rel and RelArequire during B-cell maturation involve the regulation of Bcl-2 expression. EMBO J., v. 19, n. 23, p. 6351-6360, 2000.

GUTKIND, J.S. Cell growth control by $G$ protein-coupled receptors: from signal transduction to signal integration. Oncogene, v. 17, p. 1331-1342, 1998.

HAWES, B.E.; BIESEN, T.V.; KOCH, V.J.; LUTTRELL, L.M.; LEFKOWITZ, R.J. Distinct pathways of $G_{i}$ and $G_{q}$-mediate mitogen-activated protein kinase activation. J. Biol. Chem., v. 270, n. 29, p. 17148-17153, 1995.

HAYDEN, M.S; GHOSH, S. Signaling to NF-kappa B. Genes Dev., v. 18, n. 18, p. 2195-2224, 2004.

HERMANS, E. Biochemical and pharmacological control of the multiplicity of coupling at G-protein-coupled receptors. Pharmacol. Ther., v. 99, p. 25-44, 2003.

HIPKAEO, W.; WAKAYAMA, T.; YAMAMOTO, M.; ISEKI, S. Expression and localization of the transcription factor JunD in the duct system of mouse submandibular gland. J. Histochem. Citochem., v. 52, n. 4, p. 479-490, 2004.

HUANG, Z.; WU, L.L.; ZHANG, Y.Y.; GAO, Y.; YU, G.Y. Functionl $\alpha 1$-adrenoceptor subtypes in human submandibular glands. J. Dent. Res., v. 85, n. 3, p. 251-256, 2006.

HUXFORD, T. San Diego State University Chemistry and Biochemistry. Disponível em:<http://www.chemistry.sdsu.edu/faculty/Huxford $>$. Acesso em: 1 Out. 2007.

IM, Y.B.; WON, J.S.; SUH, H.W.; HUH, S.O.; KIM, Y.H.; SONG, D.K. Differential effects of noradrenaline on the hepatic expression of immediate early genes in mice. J. Auton. Pharmacol., v. 18, p. 149-155, 1998.

IWAKI, K.; SUKHATMA, V.P.; SHUBEITA, H.E.; CHIEN, K.R. Alpha- and betaadrenergic stimulation induces distinct patterns of immediate early gene expression in neonatal rat myocardial cells. fos/jun expression is associated with sarcomere assembly; Egr-1 induction is primarily an alpha 1-mediated response. J. Biol. Chem., v. 265, p. 13809-13817, 1990.

JAMIESON, J. D.; PALADE, G. E. Intracellular transport of secretory proteins in the pancreatic exocrine cell. I Role of the peripheral elememts of the Golgi complex. J. Cell Biol., v. 34, p. 577-596, 1967 . 
JAMIESON, J. D.; PALADE, G. E. Intracellular transport of secretory proteins in the pancreatic exocrine cell. II Transport to condensing vacuoles and zymogen granules. J. Cell Biol., v. 34, p. 597-615, 1967 b.

JOHNSON, D.A. Changes in rat parotid saliva protein composition following chronic reserpine treatment and their relation to inanition. Arch. Oral Biol., v. 33, n.7, p. 463466, 1988.

JUNQUEIRA, L.C.; CARNEIRO, J. Histologia Básica. In: Glândulas Anexas do tubo digestivo. 10. ed. Rio de Janeiro: Guanabara Koogan, 2004. p. 270-286.

KARDONG, K.V. The evolution of snakes apparatus in snakes from colubrids to viperids \& elapids. Mem. Inst. Butantan, v. 46, p. 105-118, 1982.

KARIN, M. The regulation of AP-1 activity by mitogen-activated protein kinases. J. Biol. Chem., v. 270, n. 28, p. 16483-16486, 1995.

KARIN, M.; LIU, Z.G.; ZANDI, E. AP-1 function and regulation. Curr. Opin. Cell Biol., v. 9, p. 240-246, 1997.

KARIN, M.; BEN-NERIAH, Y. Phosphorylation meets ubiquitination: The control of NFкB activity. Annu. Rev. Immunol., v. 18, p. 621-663, 2000. Review.

KERCHOVE, C.M.; CARNEIRO, S.M.; MARKUS, R.P.; YAMANOUYE, N. Stimulation of the $\alpha$-adrenoceptor triggers the venom production cycle in the venom gland of Bothrops jararaca. J. Exp. Biol., v. 207, p. 411-416, 2004.

KERCHOVE, C.M. Adrenoceptor alfa da glândula de veneno da serpente Bothrops jararaca: aspectos funcionais e moleculares. $115 \mathrm{f}$. Tese (Doutorado em Biologia Celular e Tecidual) - Instituto de ciências Biomédicas, Universidade de São Paulo, São Paulo, 2005.

KERCHOVE, C.M.; LUNA, M.S.A.; ZABLITH, M.B.; SMAILI, S.S.; YAMANOUYE, N. $\alpha_{1}$-adrenoceptor trigger the snake venom production cycle in secretory cells by activating phosphatidylinositol 4,5-biphosphate hydrolysis and the ERK signaling pathway. J. Physiol. Pharmacol. In press. 
KLEIN, R.M. Development, structure and function of the salivary glands. In: AVERY, J.K. Oral Development and History. Stuttgart: Thieme, 2002. p. 321-330.

KOCHVA E.; GANS, C. The structure of the venom gland and secretion of venom in viperid snakes. In: REWELL, F.E.; RUSSELL, P.R. Animal Toxins. Oxford: Pergamon Press, 1967. p. 195-203.

KOCHVA, E. The origin of snakes and evolution of the venom apparatus. Toxicon, v. 25, n. 1, p. 65-106, 1987.

KOCHVA, E. Oral glands of the Reptilia. In: GANS, C. Biology of the Reptilia. London: Academic Press, v. 8b, 1978. p. 43-161.

KOLAKOWSKI, L.F.Jr. GCRDb: a G-protein-coupled receptor database. Recept. Channels, v. 2, n. 1, p. 1-7, 1994.

KOSHIMUZU, T.A.; TANOUE, A.; HIRASAWA, A.; YAMAUCHI, J. TSUJIMOTO, G. Recent advances in $\alpha_{1}$-pharmacology. Pharmacol. Ther., v. 98, p. 235-244, 2003.

LACASSAGNE, A. Dimorphisme sexuel de la glande sous-maxillaire chez la souris. C. R. Soc. Biol., v. 133, p. 180-181, 1940.

LAEMMLI, U.K. Cleavage of structural proteins during the assembly of the heat of bacteriophage T4. Nature, v. 227, n. 5259, p. 680-685, 1970.

LI, Y.M.; ZHANG, Y.; XIANG, B.; ZHANG, Y.Y.; WU, L.L.; YU, G.Y. Expression and functional analysis of $\beta$-adrenoceptor subtypes in rabbit submandibular gland. Life Sci., v. 79, p. 2091-2098, 2006.

LYMPEROPOULOS, A.; KARKOULIAS, G.; KOCH, W.J.; FLORDELLIS, C.S. $\alpha 2-$ Adrenergic receptor subtype-specific activation of NFKB in PC12 cells. Neurosci. Lett., v. 402, p. 210-215, 2006.

MACKESSY, S.P. Morphology and ultrastructure of the venom glands of the northen Pacific rattlesnake Crotalus viridis oreganus. J. Morphol., v. 208, p. 109-128, 1991. 
MARTINEZ, J.R.; ADSHEAD, P.C.; QUISSELL, D.O.; BARBERO, G.J. The chronically reserpinized rats as a possible model for cystic fibrosis. I. Submaxillary gland morphology and ultrastructure. Pediatr. Res., v. 9, n. 5, p. 463-469, 1975a.

MARTINEZ, J.R.; ADSHEAD, P.C.; QUISSELL, D.O.; BARBERO, G.J. The chronically reserpinized rats as a possible model for cystic fibrosis. II. Comparison and cilioinhibitory effects of submaxillary saliva. Pediatr. Res., v. 9, n. 5, p. 470-475, 1975b.

MARINISSEN, M.J.; GUTKIND, J.S. G-protein-coupled receptors and signaling networks: emerging paradigms. Trends Pharmacol. Sci., v. 22, n. 7, p. 368-376, 2001. Review.

McBRIDE, K.; NEMER, M. The C-Terminal domain of $c$-fos is required for activation of an AP-1 site specific for jun-fos heterodimers. Mol. Cell Biol., v. 18, n. 9, p.50735081, 1998.

MECHTA-GRIGORIOU, F.; GERALD, D.; YANIV, M. The mammalian Jun proteins: redundancy and specificity. Oncogene, v. 20, n. 19, p. 2378-2389, 2001.

MEIER, J. Individual and age-dependent variations in the venom of the fer-de-lance (Bothrops atrox). Toxicon, v. 24, p. 41-46, 1986.

MELDOLESI, J. Regulation of pancreatic exocrine secretion. Pharmacol. Res. Commun., v. 8, p. 1-24, 1976.

MELDRUM, D.R.; CLEVELAND, J.C.Jr.; SHERIDAN, B.C.; ROWLAND, R.T.; SELZMAN, C.H.; BANERJEE, A.; HARKEN, A.H. $\alpha$-Adrenergic activation of myocardial NFKB during hemorrhage. J. Surg. Res., v. 69, p. 268-276, 1997.

MELGAREJO, A.R. Serpentes peçonhentas do Brasil. In: Animais Peçonhentos no Brasil: Biologia, Clínica e Terapêutica dos acidentes. São Paulo: Sarvier, 2003. p. 33-61.

MENEZES, M.C.; FURTADO, M.F.; TRAVAGLIA-CARDOSO, S.R.; CAMARGO, A.C.M.; SERRANO, S.M.T. Sex-based individual variation of snake venom proteome among eighteen Bothrops jararaca siblings. Toxicon, v. 47, p. 304-312, 2006. 
MICHELOTTI, C.A.; PRICE, D.T.; SCHWINN, D.A. Alpha 1-adrenergic receptor regulation: basic science and clinical implications. Phamacol. Ther., v.88, p. 281309, 2000.

MINNEMAN, K. Heterodimerization and surface localization of $\mathrm{G}$ protein coupled receptors. Biochem. Pharmacol., v. 73, n. 8, p. 1043-1050, 2007.

MONTEIRO, R.Q.; YAMANOUYE, N.; CARLINI, C.R.; GUIMARÃES, J.A.; BON, C.; ZINGALI, R.B. Variability of bothrojaracin isoforms and other venom principle in individual jararaca (Bothrops jararaca) snakes maintained under seasonally invariant conditions. Toxicon, v. 36, p. 153-163, 1998a.

MONTEIRO, R.Q.; DUTRA D.L.; MACHADO, O.L.; CARLINI, C.R.; GUIMARÃES, J.A.; BON, C.; ZINGALI, R.B. Bothrops jararaca snakes produce several bothrojaracin isoforms following an individual pattern. Comp. Biochem. Physiol. B. Biochem. Mol. Biol., v. 120, p. 791-798, 1998 b.

NISHIURA, T.; GAO, C.; ABE, N.K. Expression and postnatal changes of adrenergic receptor subtype mRNA in rat submandibular glands. Arch. Oral Biol., v. 46, p. 573584, 2001.

NUNEZ BURGOS, G.B.; GONÇALVES, L.R.C.; FURTADO, M.F.D.; FERNANDES, W.; NICOLAU, J. Alteration of the protein composition of Bothrops jararaca venom and venom gland by isoproterenol treatment. Int. J. Biochem., v. 25, p. 1491-1496, 1993.

OKAZAKI, M.; HU, Z.W.; FUGINAGA, M.; HOFFMAN, B.B. $\alpha_{1}$-Adrenergic receptorinduced c-fos gene expression in rat aorta and cultured smooth muscle cells. J. Clin. Invest., v. 94, p. 210-218, 1994.

ONDETTI, M.A.; WILLIANS, N.J.; SABO, E.F.; PLUSCEC, J.; WEAVER, E.R.; KOCY, O. Angiotensin-converting enzyme inhibitors from the venom of Bothrops jararaca: Isolation, elucidation of structure, ands synthesis. Biochemistry, v. 10, p. 4033-4039, 1971.

ORON, U.; BDOLAH, A. Regulation of protein synthesis in the venom gland of Viperidae snake. Toxicon, v. 56, p. 177-190, 1973.

PINKSTAFF, C.A. Salivary gland sexual dimorphism: A brief review. Eur. J. Morphol., v.36, p. 31-34, 1998.

PROCTOR, G.B; CARPENTER, G.H. Regulation of salivary gland function by autonomic nerves. Auton. Neurosci. Basic Clin., v. 133, p. 3-18, 2007. Review. 
QUISSEL, D.O.; BARZEN, K.A.; DEISHER, L.M. Rat submandibular and parotid protein phosphorylation and exocytosis: Effect of site-selective cAMP analogs. Crit. Rev. Oral Biol. Med., v. 4, p. 443-448, 1993.

ROCHA E SILVA, M.; BERALDO, W.T.; ROSENFELD, G. Bradykinin, a hypotensive and smooth muscle stimulating factor released from pfasma globulin by snake venoms and by trypsin. Am. J. Physiol., v. 156, p. 261-273, 1949.

RONG, Y.; BAUDRY, M. Seizure activity results in a rapid induction of nuclear factor$\kappa \mathrm{B}$ in adult but not juvenile rat limbic structures. J. Neurochem., v. 67, p. 662-668, 1996.

ROTENBERG, D.; BAMBERGER, E.S.; KOCHVA, E. Studies on ribonucleic and synthesis in the venom glands of Vipera palaestinae (Ophidia, reptilia). Biochem. J., v. 121, n. 4, p. 609-612, 1971.

SALOMÃO, M.G. Estrutura e secreção das glândulas de Duvernoy de Sibynomorphus mikani (Colubridae, Dipsadinae) e Philodryas olfersii (Colubridae, Xenodontinae), e das glândulas de veneno de Bothrops jararaca (Viperidae, Crotalinae) e Micrurus frontalis (Elapidae, Elapinae) e a influência dos estados de alimentação e jejum. 122 f. Tese (Doutorado em Zoologia) Instituto de Biociências, Universidade de São Paulo, São Paulo, 1991.

SAZIMA, I. Estudo da biologia comportamental da jararaca, Bothrops jararaca, com uso de marcas naturais. Mem. Inst. Butantan, v. 50, p. 83-99, 1988.

SCHAEFFER, R.C.Jr.; BERNICK, S.; ROSENQUIST, H.; RUSSELL, F.E. The histochemistry of the venom glands of the rattlesnake Crotalus viridis helleri - I Lipid and non-specific esterase. Toxicon, v.10, n. 2, p. 183-186, 1972a.

SCHAEFFER, R.C.Jr.; BERNICK, S.; ROSENQUIST, H.; RUSSELL, F.E. The histochemistry of the venom glands of the rattlesnake Crotalus viridis helleri - II Monoamine oxidade, acid and alkaline phosphatase. Toxicon, v. 10, n. 2, p. 295297, $1972 b$.

SCHAEFFER, H.J.; WEBER, M.J. Mitogen-activated protein kinases: specific messages from ubiquitous messengers. Mol. Cell. Biol., v. 19, n. 4, p. 2435-2444, 1999. 
SCHILLING, K.; LUK, D.; MORGAN, J. I.; CURRAN, T. Regulation of a fos-lacZ fusion gene: A paradigm for quantitative analysis of stimulus-transcription coupling.

Proc. Natl. Acad. Sci. USA, v. 88, p. 5665-5669, 1991.

SCHIÖTH, H.B.; FREDRIKSSON, R. The GRAFS classification system of G-protein coupled receptors in comparative perspective. Gen. Comp. Endocrinol., v. 142, p. 94-101, 2005.

SCHNEYER, C.A. Salivary gland changes after isoproterenol-induced enlargement. Am. J. Physiol., v. 203, p. 232-236, 1962.

SEN, R.; BALTIMORE, D. Multiple nuclear factors interact with the immunoglobulin enhancer sequences. Cell, v. 46, p. 705-716, 1986.

SELYE, H.; VEILLEUX, R.; CANTIN, M. Excessive stimulation of salivary gland growth by isoproterenol. Science, v. 133, p. 44-45, 1961.

STAAL, F.J.T.; ROEDERER, M.; HERZENBERG, L.A.; HERZENBERG, L.A. Intracellular tilos regulate activation of nuclear factor $\kappa \mathrm{B}$ and transcription o human immunodeficiency virus. Proc. Natl. Acad. Sci. USA, v. 87, p. 9943-9947.

TAIMOR, G.; SCHLÜTER, K.D.; BEST, P.; HELMING, S.; PIPER, H.M. Transcription activator protein 1 mediates $\alpha$ - but not $\beta$-adrenergic hypertrophic growth reponses in adult cardiomyocytes. Am. J. Physiol. Heart Circ. Psysiol., v. 286, p. H2369H2375, 2004.

TAM, W.F.; SEN, R. I B Family members function by different mechanisms. J. Biol. Chemistry, v. 276, cap. 11, p. 7701-7704, 2001.

TEN HAGEN, K.G.; BALYS, M.M.; TABAK, L.A.; MELVIN, J.E. Analysis of isoproterenol-induced changes in parotid gland gene expression. Physiol. Genomics, v. 8, p. 107-114, 2002.

THONBERG, H.; ZHANG, S.J.; TVRDIK, P.; JACOBSSON, A.; NEDERGAARD, J. Norepinephrine utilizes $\alpha_{1}$ - and $\beta$-adrenoceptors synergistically to maximally induce c-fos expression in brown adipocytes. J. Biol. Chem., v. 269, p. 33179-33186, 1994.

TANOUE, T.; NISHIDA, E. Molecular recognitions in the MAP kinase cascades. Cell. Signal., v. 15, p. 455-462, 2003. 
TREISTER, N.S.; RICHARDS, S.M.; LOMBARDI, M.J.; ROWLEY, P.; JENSEN, R.V.; SULLIVAN, D.A. Sex-related differences in gene expression in salivary glands of BALB/c Mice. J. Dent. Res., v. 84, n. 2, p. 160-165, 2005.

TURJANSKI, A.J.; VAQUÉ, J.P.; GUTKIND, J.S. MAP Kinases and the control of nuclear events. Oncogene, v. 26, p. 3240-3253, 2007.

UEZONO, Y.; KAIBARA, M.; MURASAKI, O.; TANIYAMA, K. Involviment of G protein $\beta \gamma$-subunits in diverse signaling induced by $\mathrm{G}_{\mathrm{i}} / \mathrm{o}_{\mathrm{o}}$-coupled receptors: study using Xenopus oocyte expression system. Am. J. Physiol. Cell Physiol., v. 287, p. C885C894, 2004.

VULGMAN, I.; HAND, A.R. Quantitative immunocytochemical study of secretory protein expression in parotid glands of rats chronically treated with isoproterenol. Microsc. Res. Tech., v. 31, p. 106-117, 1995.

WARRELL, D.A. Snake venoms in science and clinical medicine. 1.Russell's viper: biology, venom and treatment of bites. Trans. R. Soc. Trop. Med. Hyg., v. 83, n. 6, p. 732-740, 1989.

WATSON, E.; DOWD, F.; JACOBSON, K.; HORWITZ, H. Reserpinization: Effects on parotid gland and function. J. Dent. Res., v. 63, p. 82-86, 1984.

WESTWICK, J.K.; SCHWAMBORN, K.; MERCURIO, F. NFאB: A Key integrator of cell signaling. In: BRADSHAW, R.A.; DENNIS, E.A. Handbook of Cell Signaling, San Diego, California: Academic Press, v. 3, 2004. p. 107-114.

WHITESIDE, S.T.; ISRAËL, A. IאB proteins: structure, function and regulation. Semin. Cancer Biol., v. 8, p. 75-82, 1997.

WILLIAMS, N.J.; ZHONG, H.; MINNEMAN, K.P. Differential coupling $\alpha_{1^{-}}, \alpha_{2^{-}}$and $\beta-$ adrenergic receptors to mitogen-activated protein kinase pathways and differentiation in transfected PC12 cells. J. Biol. Chem., v. 273, n. 38, p. 24624-2432, 1998.

WOON, P.Y.; JEYASEELAN, K.; THIYAGARAJAH, P. Adrenergic regulation of RNA synthesis in the rat parotid gland. Biochem. Pharmacol., v. 45, n. 7, p. 1395-1401, 1993. 
XIANG, B.; ZHANG, Y.; LI, Y.M.; ZHANG, Y.Y.; WU, L.L.; YU, G.Y. Effects of Phenylephrine on transplanted submandibular gland. J. Dent. Res., v. 85, n. 12, p.1106-1111, 2006.

XIAO, R.P.; ZHU, W.; ZHENG, M.; CHAKIR, K.; BOND, R.; LAKATTA, E.G.; CHENG, H. Subtype-specific $\beta$-adrenoceptor signaling pathways in the heart and their potential clinical implications. Trends Pharmacol. Sci., v. 25, p. 358-365, 2004.

YAMADA, K.; INOUE, H.; KIDA, S.; MASUSHIGE, S.; NISHIYAMA, T.; MISHIMA, K.; SAITO, I. Involvement of CAMP response element-binding protein activation in salivary secretion. Pathobiology, v. 73, p. 1-7, 2006.

YAMANOUYE N.; BRITTO, L.R.G.; CARNEIRO, S.M.; MARKUS, R.P. Control of venom production and secretion by sympathetic outflow in the snake Bothrops jararaca. J. Exp. Biol., v. 200, p. 2547-2556, 1997.

YAMANOUYE N.; CARNEIRO, S.M.; SCRIVANO, C.N. MARKUS, R.P. Characterization of $\beta$-adrenoceptors responsible for venom production in the venom gland of the snake Bothrops jararaca. Life Sci., v. 67, p. 217-226, 2000.

YAMANOUYE, N.; KERCHOVE, C.M.; MOURA-DA-SILVA, A.M.; CARNEIRO, S.M.; MARKUS, R.P. Long-term primary culture of secretory cells of Bothrops jararaca venom gland for venom production in vitro. Nature Protoc., v. 1, n. 6, p. 2763-2766, 2007.

YAMAUCHI, J.; HIRASAWA, A.; MIYAMOTO, Y.; ITOH, H.; TSUJIMOTO, G. $\beta_{2^{-}}$ Adrenergic receptor/cyclic adenosine monophosphatase (cAMP) leads to JNK activation through Rho family small GTPases. Biochem. Biophys. Res.Commun., v. 284, p. 1199-1203, 2001.

YEH, C.K.; GHOSH, P.M.; DANG, H.; LIU, Q.; LIN, A.L.; ZHANG, B.X.; KATZ, M.S. $\beta$-Adrenergic-responsive activation of extracellular signal-regulated protein kinases in salivary cells: role of epidermal growth factor receptor and CAMP. Am. J. Physiol. Cell Physiol., v. 288, p. C1357-C1366, 2005.

YOSHIE, W.; ISHIYAMA, M.; OGAWA, T. Fine structure of Duvernoy's gland of the Japanese colubrid snake, Rhabdophis tigrinus. Arch. Histol. Jpn., v. 45, p. 375-384, 1882. 
ZABLITH, M.B. Vias de sinalização desencadeadas pela estimulação do adrenoceptor $\beta$ em células secretoras da glândula de veneno da serpente Bothrops jararaca. 78 f. Tese (Mestrado em Ciências) - Instituto de ciências Biomédicas, Universidade de São Paulo, São Paulo, 2007.

ZAGO, D.A. Estudo morfológico e histoquímico de glândulas salivares relacionadas com a evolução da função venenosa nos ofídeos. $69 \mathrm{f}$. Tese (Doutorado em Histologia e Embriologia) - Instituto de Ciências Biomédicas, Universidade de São Paulo, 1971.

ZINGALI, R.B. JANDROT-PERRUS, M.; GUILLIN, M.C.; BON, C. Bothrojaracina, a new thrombin inhibitor isolated from Bothrops jararaca venom: characterization and mechanism of thrombin inhibition. Biochemistry, v. 32, p. 10794-10802, 1993.

ZINGALI, R.B.; FERREIRA, M.S.; ASSAFIM, M. FRATTANI, F.S.; MONTEIRO, R.Q. Bothrojaracin, a Bothrops jararaca snake-venom derivad (Pro) thrombin inhibitor, as an anti-thrombotic molecule. Pathophysiol. Haemost. Thromb., v. 34, p. 160-163, 2005.

ZHENG, M.; ZHANG, S,J.; ZHU, W.Z.; ZIMAN, B.; KOBILKA, B.K.; XIAO, R.P. $\beta_{2^{-}}$ Adrenergicreceptor-induced p38 MAPK activation is mediated by protein kinase $A$ rather than by $\mathrm{G}_{i}$ or $\mathrm{G}_{\beta \gamma}$ in adult mouse cardiomyocytes. J. Biol. Chem., v. 275, n. 51, p. 40365-40640, 2000.

ZHONG, J.; HUME, J.R.; KEEF, K.D. $\beta$-Adrenergic receptor stimulation of L-type $\mathrm{Ca}^{2+}$ channels in rabit portal vein myocytes involves both $\alpha_{s}$ and $\beta \gamma \mathrm{G}$ protein subunits. J. Physiol., v. 531, n. 1, p. 105-115, 2001. 